\title{
OCHRANA SOUKROMÍ V ČESKO-SLOVENSKÝCH CHYTRÝCH KARANTÉNÁCH
}

\author{
ŠIMON CHVOJKA ${ }^{1}$
}

\begin{abstract}
ABSTRAKT
Technologická vyspělost obecné populace je vysoká, což vládám umožnilo využít moderních technologií v boji proti koronaviru. Článek se zaměřuje na oficiální chytré karantény $v$ České a Slovenské republiCE, které popisuje a analyzuje z pohledu práva na soukromí a ochranu osobních údajů. Největši zjištěné problémy se týkají nedostatečnosti aplikovatelných právních rámců a také proporcionality využitého řešení. $V$ obou př́padech přitom šlo o problémy, kterým se bylo možné vyhnout.
\end{abstract}

\section{KLÍČOVÁ SLOVA}

Chytrá karanténa; ochrana soukromí; eRouška, eKaranténa; COVID-19

\begin{abstract}
The technological advancement of the general population is high, which has allowed governments to use modern technologies to combat the coronavirus. This paper focuses on the official smart quarantines in the Czech and Slovak Republics, which it describes and analyses from the right to privacy and personal data protection's point of view. The biggest problems identified relate to insufficient
\end{abstract}

\footnotetext{
Mgr. Šimon Chvojka je absolventem Právnické fakulty Masarykovy univerzity v Brně. Kontaktní e-mail: 458884@muni.cz. Stav textu je k 31. 3. 2021. Tento článek vychází ze SVOČ zpracované v roce 2021. Autor by na tomto místě rád poděkoval za cenné připomínky a rady JUDr. MgA. Jakubovi Míškovi, Ph.D.
} 
applicable legal frameworks and to the proportionality of the used solution. In both cases, the problems were avoidable.

\section{KEYWORDS}

Smart quarantine; privacy protection; eRouška, eKaranténa; COVID-19

\section{1. ÚVOD}

Na začátku března 2020 byly na území České republiky potvrzeny první případy nákazy koronavirem označovaného jako SARS-CoV-2, a jinak tomu nebylo na Slovensku. Rok se s rokem sešel, a to tradičně nabízí prostor pro bilancování. V tomto příspěvku bude věnován prostor tzv. chytrým karanténám.

Právě jejich nasazením se (nejen) státy Evropské unie („EU“) snaží omezit přenos viru. Ačkoliv se jejich podoba liší stát od státu, obecně lze konstatovat, že ve středu zájmu jsou mobilní telefony občanů. ${ }^{2}$ Ty totiž jednoduše umožňují sledovat pohyb majitele, at už skrze systém GPS, antény telefonních operátorů anebo technologii Bluetooth. Právě technologický rozvoj těchto funkcí spolu se zvyšujícím se počtem uživatelů mobilních telefonů umožnili první masové využití chytrých karantén. Plošnost nasazení na druhou stranu indikuje možnost závažného zásahu do základních práv občanů na soukromí a informační sebeurčení. Je tomu skutečně tak? A jedná se případně o proporcionální zásah?

$\mathrm{Na}$ tyto otázky se příspěvek snaží najít odpověd'. Situaci zkoumá na příkladu oficiálních chytrých karantén v České republice a Slovenské republice. Zaměřuje se především na chaotické období první vlny na jaře 2020, kdy se státy v jisté bezradnosti, snad někdy i bezhlavě, snažily co nejefektivněji využít moderní technologie $\mathrm{k}$ potlačení rychle se šírícího viru.

Východiskem pro hodnocení jsou zejména veřejně dostupné údaje (právní rámec, publikované informace o projektech, informační povinnosti správců) ale také posouzení vlivu na ochranu osobních údajů („DPIA“)

2 Pro přehled jednotlivých států a jejich chytrých karantén srov. Projects using personal data to combat SARS-CoV-2. In: GDPRHUB.eu [online] [cit. 12. 4. 2020]. Dostupné z: https:// gdprhub.eu/index.php?title $=$ Projects_using_personal_data_to_combat_SARS-CoV-2 
$\mathrm{k}$ jednotlivým řešením, které byly získány prostřednictvím zákonů o svobodném přístupu $\mathrm{k}$ informacím.

Cílem článku je komplexně popsat fungování chytrých karantén z pohledu práva, následně je podrobit kritickému zhodnocení (zejména jejich proporcionalitu) a př́ípadně upozornit na vybrané nedostatky v postupu odpovědných míst.

V první části je podán všeobecný přehled relevantní právní úpravy ochrany soukromí a osobních údajů v Česku a na Slovensku, který se s chytrými karanténami pojí. Druhá část popisuje fungování jednotlivých částí chytrých karantén $\mathrm{v}$ obou zemích $\mathrm{v}$ průběhu první vlny. Třetí část je částí analytickou. Popsaný stav je podroben kritickému zhodnocení z pohledu ochrany soukromí obyvatel a principů ochrany osobních údajů. Vybrané problémy jsou rozebrány podrobněji, a to i s přihlédnutím k případnému vývoji jednotlivých prezentovaných řešení.

\section{OCHRANA SOUKROMÍ A OSOBNÍCH ÚDAJŮ...}

Ochrana soukromí a osobních údajů v Česku a na Slovensku je téměř identická - oba státy jsou signatáři Evropské úmluvy o ochraně základních práv a lidských svobod („Úmluva“), členy EU a národní listiny práv jsou podobné. Popis právního rámce ochrany tak je rozdělen podle těchto tř́ okruhů.

Obecně je nutné před začátkem konstatovat, že existence krizové situace není automaticky di̊vodem pro benevolentnější přístup $\mathrm{k}$ hodnocení zásahů do základních lidských práv. Vláda práva musí fungovat i v časech krize. ${ }^{3}$ To potvrzují i recentní rozhodnutí českých soudů, které jsou v případě přezkumu opatření z počátku pandemie benevolentnější ale s postupujícím časem požadavky (zejm. na odůvodnění) stupňují. ${ }^{4}$

3 Respecting democracy, rule of law and human rights in the framework of the COVID-19 sanitary crisis: A toolkit for member states [online]. Council of Europe, 2020, s. 3 [cit. 14. 5. 2020]. Dostupné z: https://rm.coe.int/sg-inf-2020-11-respecting-democracy-rule-of-law-and-human-rights-in-th/16809e1f40

4 Srov. rozsudek Městského soudu v Praze ze dne 13. 11. 2020, č. j. 18 A 59/2020-226, odst. 142 a tam citovanou judikaturu. 


\section{1 ...JAKO SOUČÁST ÚMLUVY}

Přímo v čl. 8 Úmluvy zabývajícím se soukromím, ${ }^{5}$ a ani nikde jinde v Úmluvě, nenajdeme ochranu osobních údajů explicitně zmíněnu. Dosah Úmluvy i na osobní údaje vyplývá až z jejího výkladu podávaného Evropským soudem pro lidská práva („ESLP“), který má v tomto směru poměrně bohatou judikaturu. ${ }^{6}$ Dle něj se jedná o jeden ze základních aspektů práva na soukromý a rodinný život. ${ }^{7}$ Ochrana osobních údajů je základním předpokladem práva na soukromí. ${ }^{8}$

V pojetí ESLP se za osobní údaj považují informace, které se vztahují na identifikované nebo identifikovatelné jedince (tzn. obsahují informace osobního charakteru). ${ }^{9}$ Při určení obsahu informací bere ESLP v úvahu kontext jejich získání a uložení, povahu, způsob použití a nakládání s nimi a také, co z nich může být dovozeno. ${ }^{10}$ Př́kladem, kdy informace je osobním údajem ve smyslu judikatury ESLP je tzv. zvláštní kategorie osobních údajư ${ }^{11}$ nebo bankovní dokumenty. ${ }^{12}$

5 Čl. 8 Úmluvy zní:

„1. Každý má právo na respektování svého rodinného a soukromého života, obydlí a korespondence.

2. Státní orgán nemůže do výkonu tohoto práva zasahovat kromě př́padů, kdy je to $v$ souladu se zákonem a nezbytné $v$ demokratické společnosti $v$ zájmu národní bezpečnosti, veřejné bezpečnosti, hospodárského blahobytu země, ochrany pořádku a předcházení nepokojům a zločinnosti, ochrany zdraví nebo morálky nebo ochrany práv a svobod jiných."

6 Guide on Article 8 of the European Convention on Human Rights [online]. Evropský soud pro lidská práva, 2020, s. 38 an. a 44 an. [cit. 1. 9. 2020]. Dostupné z: https://www.echr.coe.int/documents/guide_art_8_eng.pdf

7 Ibid., s. 39.

8 Např. S. a Marper proti Spojenému království, rozsudek ESLP, 4. 12. 2008 č. stížnosti 30562/04 a 30566/04, odst. 103; nebo Satakunnan Markkinapörssi Oy And Satamedia Oy proti Finsku, rozsudek ESLP, 27. 6. 2017 č. stížnosti 931/13, odst. 137.

9 S. a Marper proti Spojenému království, rozsudek ESLP, odst. 68; a P. a S. proti Polsku, rozsudek ESLP, 30. 10. 2012 č. stížnosti 57375/08, odst. 130.

${ }^{10}$ S. a Marper proti Spojenému království, rozsudek ESLP; odst. 67 a tam citovaná judikatura.

11 Dříve označované jako tzv. citlivé údaje. Guide on Article 8 of the European Convention on Human Rights, odst. 173.

12 Ibid. 
Už jenom samotné zaznamenání těchto údajů následně zakládá zásah do soukromí, ${ }^{13}$ není vyžadováno jejich využití. ${ }^{14} \mathrm{~V}$ takových př́ípadech je nutné posoudit, zda je tento zásah $\mathrm{v}$ souladu $\mathrm{s}$ Úmluvou. Toto zjištění se provádí za pomoci testu stanoveným čl. 8 odst. 2 Úmluvy, který se označuje jako tzv. pětistupňový test (aplikovatelnost Úmluvy; existence zásahu; legalita; legitimní cíl; nezbytnost v demokratické společnosti). ${ }^{15} \mathrm{~V}$ tomto článku budou klíčové zejména dva jeho kroky: legalita a nezbytnost.

Aby byl zásah legální, je nutné jej učinit na základě dostatečně kvalitního právního základu. Kvalitu práva ESLP určuje prostřednictvím jeho dostupnosti a předvídatelnosti ve spojení s existencí záruk proti svévoli veřejných orgánů př̀ aplikaci práva. ${ }^{16}$

$\mathrm{V}$ př́ípadě nezbytnosti $\mathrm{v}$ demokratické společnosti se zkoumá, zda zásah odpovídal naléhavé společenské potřebě a zda byl přiměřený sledovanému legitimnímu cíli. Komentár uvádí, že tento krok funguje jako black box jedná se o nejméně předvídatelný krok. Obecně je ale možné konstatovat, že v potaz bere ESLP důležitost chráněného práva, (ne)existenci evropského konsenzu, důležitost zájmu na zásahu a rozsah zásahu. ${ }^{17}$

Dle čl. 15 Úmluvy je státům umožněno suspendovat závazky, které jim z čl. 8 Úmluvy vyplývají. Česká ani Slovenská republika této možnosti nevyužily, ${ }^{18}$ a tak se Úmluva uplatňuje na jejich systémy chytrých karantén $\mathrm{v}$ plném rozsahu.

V rámci právního rámce mezinárodní organizace Rady Evropy, pod kterou Úmluva spadá, je nutné zmínit i tzv. Úmluvu $108 .{ }^{19}$ Tato úmluva nastavuje obecné principy zpracování osobních údajů. Dále představené ná-

13 S. a Marper proti Spojenému království, rozsudek ESLP, odst. 67.

14 Leander proti Švédsku, rozsudek ESLP, 26. 3. 1987, č. stížnosti 9248/81, odst. 48.

15 K tomu blíže srov. KMEC, Jiří et al. Evropská úmluva o lidských právech: komentář. Praha: C.H. Beck, 2012, s. 99.

16 Ibid., s. 106-109.

17 Ibid., s. 113-117.

18 Notifications under Article 15 of the Convention in the context of the COVID-19 pandemic. In: Council of Europe [online] [cit. 18.02.2021]. Dostupné z: https://www.coe.int/en/web/ conventions/full-list/-/conventions/webContent/62111354

19 Úmluva o ochraně osob se zřetelem na automatizované zpracování osobních dat, která byla vyhlášena pod č. 115/2001 Sb. m. s. 
stroje regulace ovšem představují mnohem detailnější úpravu práv a povinností, $^{20}$ a proto bude pozornost věnována především jim. Poukázat se v tomto ohledu dá pak i na další dokumenty Rady Evropy vydané v průběhu pandemie. ${ }^{21}$

\section{2 ... PODLE PRÁVA EU}

V primárním právu EU najdeme právo na ochranu osobních údajů jak v čl. 16 Smlouvy o fungování EU, tak v čl. 8 Listiny základních práv EU. ${ }^{22}$ Právo na respektování soukromého života je pak zakotveno v čl. 7 Listiny základních práv EU. ${ }^{23} \mathrm{~V}$ souvislosti s tímto katalogem práv je nutné připomenout jednak limity jeho aplikace dané čl. 51 odst. 1 (aplikuje se pouze v případě, že stát uplatňuje právo EU) a jednak výkladové ustanovení čl. 52 odst. 3 (povinnost výkladu obdobných práv v souladu s Úmluvou).

O aplikovatelnosti práva EU není v rámci zpracování osobních údajů v chytrých karanténách pochybností. Všechny technické způsoby, kterými Česká a Slovenská republika bojují proti koronaviru spadají pod sekundární právo EU - at̉ už se aplikují obecná pravidla pro osobní údaje stanovená v nařízení (EU) 2016/679, obecné nařízení o ochraně osobních údajů („GDPR“), nebo sektorová úprava pro ochranu elektronické komunikace upravená směrnicí 2002/58/ES, která stanovuje možnosti zpracování údajů sbíraných mobilními operátory při poskytování služeb.

20 DE TERWANGNE, Cécile. Council of Europe convention 108 +: A modernised international treaty for the protection of personal data. Computer Law \& Security Review. 2021, roč. 40, s. 3. DOI: 10.1016/j.clsr.2020.105497

${ }^{21}$ Např. PIERUCCI, Alessandra a Jean-Philippe WALTER. Joint Statement on the right to data protection in the context of the COVID-19 pandemic. In: Council of Europe [online]. 2020 [cit. 18. 5. 2020]. Dostupné z: https://rm.coe.int/covid19-joint-statement/16809e09f4 Rozcestník k dalším relevantním dokumentům lze najít na https://www.coe.int/en/web/ data-protection/-/saving-lives-respecting-data-protecti-1.

22 Čl. 8 odst. 1 a 2 Listiny základních práv EU zní:

„1. Každý má právo na ochranu osobních údaju, které se ho týkají.

2. Tyto údaje musí být zpracovány korektně, $k$ přesně stanoveným účelům a na základě souhlasu dotčené osoby nebo na základě jiného oprávněného důvodu stanoveného zákonem. Každý má právo na př́stup $k$ údajưm, které o něm byly shromážděny, a má právo na jejich opravu."

23 Čl. 7 Listiny základních práv EU zní:

„Každý má právo na respektování svého soukromého a rodinného života, obydlí a komunikace.“ 
Pojem „osobní údaj“ je v rámci EU vykládán tzv. objektivním způsobem. To znamená, že pro posouzení údaje jako osobního postačí, pokud existuje jiná informace, která ve spojení s tou první vede k identifikaci konkrétní osoby. Tato druhá informace přitom nemusí být nutně v dispozici téže osoby, ba dokonce $\mathrm{k}$ ní ani nemusí mít přístup. ${ }^{24}$

EU je obecně v tématu ochrany osobních údajů v souvislosti s koronavirem aktivní. Na začátku krize vydala Evropská komise doporučení týkající se využití digitálních technologiî́ ${ }^{25}$ a následovaly i pokyny k chytrým aplikacím. $^{26}$

\section{3 ... V NÁRODNÍCH PRÁVNÍCH ÚPRAVÁCH}

Mimo vyjmenované předpisy mezinárodního práva a práva EU jsou soukromí a osobní údaje chráněny v České a Slovenské republice i na národní úrovni.

V České republice se jedná zejména o čl. 10 odst. 2 a 3 Listiny základních práv a svobod, které se věnují informačnímu sebeurčení. ${ }^{27}$ Zahrnují tak i právo na ochranu před sledováním a hlídáním ze strany veřejné moci. ${ }^{28}$ Při hodnocení zásahu do tohoto práva bere Ústavní soud ČR v potaz v zásadě stejné aspekty, jako ESLP při hodnocení zásahů do práva garantovaného čl. 8 Úmluvy. ${ }^{29}$

24 Rozsudek Nejvyššího správního soudu ze dne 13. 8. 2020, č. j. 1 As 387/2019-56, odst. 25-28.

25 Doporučení Komise (EU) 2020/518 ze dne 8. dubna 2020 o společné sadě nástrojů Unie pro využití technologií a dat k boji proti krizi COVID-19 a ukončování souvisejících mimořádných opatření, zejména pokud jde o mobilní aplikace a využívání anonymizovaných dat o mobilitě.

26 Sdělení Komise Pokyny k aplikacím podporujícím boj proti pandemii COVID-19 ve vztahu k ochraně údajů 2020/C 124 I/01.

27 Čl. 10 odst. 2 a 3 Listiny základních práv a svobod zní:

„(2) Každý má právo na ochranu před neoprávněným zasahováním do soukromého a rodinného života.

(3) Každý má právo na ochranu před neoprávněným shromažd’ováním, zveřejňováním nebo jiným zneuživáním údajů o své osobě. “

28 WAGNEROVÁ, Eliška et al. Listina základních práv a svobod: komentář. Praha: Wolters Kluwer, 2012, kap. Čl. 10 odst. 3.

29 Ibid. 
Z podústavních předpisů jsou pak relevantní zejména předpisy provádějící nebo implementující sekundární právo EU, jako je zákon č. 110/2019 Sb., o zpracování osobních údajů, reagující na GDPR a zákon č. 127/2005 Sb., o elektronických komunikacích („ElKomČR“), implementující směrnici 2002/28/ES. Relevantní jsou pak také některé sektorové př̀edpisy (např. ve vztahu $\mathrm{k}$ bankovnictví), které budou zmíněny dále $\mathrm{v}$ textu. $\mathrm{V}$ nich jsou totiž upraveny možnosti prolomení telefonního či bankovního tajemství.

Ústava SR obsahuje zcela totožné ustanovení o ochraně osobních údajů v čl. 16 odst. 1 a čl. 19 odst. 2 a 3 jako je v české Listině základních práv a svobod. Zákonnou úpravou poté je zákon č. 18/2018 Z. z., o ochrane osobných údajov a také zákon č. 351/2011 Z. z., o elektronických komunikáciách („ElKomSR“).

\section{POPIS CHYTRÝCH KARANTÉN}

Popsaný skutkový stav se týká zásadně prvních verzí chytrých karantén, které byly vyvinuty a nasazeny v první polovině roku 2020. Od té doby prošly oba systémy změnami, které $v$ některých případech i zcela zásadně ovlivnily jejich fungování. Tyto změny jsou reflektovány ve třetí části, kde jsou hodnoceny zásadní nedostatky přístupu obou zemí. Časový posun ovšem může přinést problém $\mathrm{v}$ dostupnosti některých odkazovaných zdrojů (např. došlo $\mathrm{k}$ aktualizaci informací pro subjekty údajů). ${ }^{30}$

\section{1 ČESKÁ REPUBLIKA}

Chytrá karanténa se v České republice na jaře 2020 skládala ze dvou hlavních větví. První byla tvorba vzpomínkových map pro preciznější dohledání kontaktů nakaženého a druhá byla aplikace eRouška sloužící pro zaznamenávání kontaktů s osobami kolem. ${ }^{31}$

${ }^{30}$ V některých případech je možné využít služby zaznamenávající snapshoty webových stránek, např. https://web.archive.org.

${ }^{31}$ Chytrá karanténa - Aktuální informace o COVID-19. In: Ministerstvo zdravotnictví ČR [online] [cit. 5. 8. 2020]. Dostupné z: https://koronavirus.mzcr.cz/chytra-karantena/ 


\subsubsection{VZPOMÍNKOVÉ MAPY}

Vzpomínkové mapy vytvářela Krajská hygienická stanice („KHS“) během telefonátu s pozitivně testovanou osobou. Mapa se využívala $\mathrm{k}$ tomu, aby tato osoba mohla určit co nejvíce ostatních osob, se kterými se v inkriminované době potkala a mohla je potenciálně nakazit. Sdělení takových údajů je součástí obecné povinnosti nakaženého poskytnout součinnost při epidemiologickém šetření podle § 62a zákona č. 258/2000 Sb., o ochraně veřejného zdraví („OchrZdrČR“).

Do vzpomínkové mapy mohla být, na základě souhlasu nakaženého, přidána i data poskytnutá bankami a telefonními operátory, ${ }^{32}$ což mělo usnadnit rozpomenutí si na všechny relevantní osoby. Pokud nakažený souhlas neudělil, vznikla vzpomínková mapa pouze z údajů, které on sám KHS sdělii..$^{33}$ Právní úprava neumožňovala předání, a ani následné zpracování v podobě vytvoření vzpomínkové mapy, na základě jiného titulu nežli souhlasu. ${ }^{34}$ Tento článek se bude dále zabývat jenom situací, ve které souhlas byl poskytnut.

Právní rámec se skládal z podzákonných předpisů, jmenovitě usnesení vlády $\mathrm{C}^{35}$ a mimořádného opatření Ministerstva zdravotnictví $\mathrm{C}^{3},{ }^{36}$ které na základě $\S 69$ odst. 1 písm. i) a odst. 2 OchrZdrČR uložilo mobilním operátorům a bankám povinnost předat dále uvedené údaje nakaženého. Dále mimořádné opatření stanovilo bližší podmínky zpracování takto poskytnutých osobních údajů. Povinnost bank a operátorů přitom, $\mathrm{z}$ důvodu povinnosti KHS získat souhlas s poskytnutím osobních údajů, přímo nekoli-

${ }^{32}$ Souhrnná DPIA Jednotný informační systém KHS pro podporu call centra a vzpomínkové mapy v. 1.09, s. 3. Po omezený čas k dispozici z: https://cutt.ly/Pk6taDW. DPIA vzpomínkových map bylo získané na základě žádosti autora podle zákona č. 106/1999 Sb., o svobodném přístupu $\mathrm{k}$ informacím. Odpověd povinného subjektu je dostupná $\mathrm{z}$ : https:// www.mzcr.cz/wp-content/uploads/2020/08/239_2020_A.pdf.

${ }^{33}$ Chytrá karanténa - Aktuální informace o COVID-19.

${ }^{34}$ NULÍČEK, Michal, Bohuslav LICHNOVSKÝ a Filip BENEŠ. Chytrá karanténa - proč v Česku potřebujeme souhlas? [online]. 2020 [cit. 5. 8. 2020]. Dostupné z: https://rowan.legal/ chytra-karantena-proc-v-cesku-potrebujeme-souhlas/

${ }^{35}$ Usnesení Vlády ČR č. 250 ze dne 18. 3. 2020, k zajištění zvýšené ochrany obyvatel - trasováním.

${ }^{36}$ Mimořádné opatření Ministerstva zdravotnictví ČR ze dne 19. 3. 2020, č.j. MZDR 12398/2020-1/MIN/KAN. 
dovala ani se zvláštní sektorovou úpravou chránící data klientů bank a mobilních operátorů. ${ }^{37}$

Mobilní operátoři poskytovali KHS údaje o vysílačích, na které se připojil mobilní telefon dané nakažené osoby. Podle vyjádření mobilního operátora byla přesnost určení na úrovni obcí či částí měst, ale již nikoliv na úrovni ulic či konkrétních domů. ${ }^{38}$ Banky předávaly údaje o době a místě použití elektronického platebního prostředku nakažené osoby, a to pouze pro oblast, která byla vydefinována na základě údajů od mobilních operátorů. ${ }^{39}$ Časový rozsah poskytnutých údajů byly až tři poslední týdny. ${ }^{40}$

Další osobní údaje vyskytující se v rámci tvorby vzpomínkových map byly jméno a příjmení osoby, její adresa, telefonní číslo, zdravotní stav, rodné číslo a kontakty na třetí osoby. ${ }^{41}$

Právním titulem pro zpracování byla zákonná povinnost poskytnutí spolupráce při epidemii podle $\S 62$ a OchrZdrČR a plnění úkolů veřejného zájmu. ${ }^{42}$ Zpracování zvláštní kategorie poté bylo prováděno na základě veřejného zájmu. ${ }^{43}$ Se souhlasem se počítalo pouze pro poskytnutí údajů od operátorů a bank, a nikoliv pro jejich další zpracování. ${ }^{44}$

Vzpomínkové mapy byly vymazány maximálně šest hodin po vytvoření. ${ }^{45}$

Jako správce zde vystupovalo Ministerstvo zdravotnictví ČR. V pozicích zpracovatelů se vyskytovaly další subjekty, mezi které patřila např. společnost Keboole, Amazon Web Services EMEA SARL, či Armáda ČR. ${ }^{46}$

${ }^{37}$ Ustanovení § 91 odst. 2 ElKomČR, jako právní úprava pro mobilní operátory, a § 38 zákona č. 21/1992 Sb., o bankách, ve vztahu k bankám.

38 KLOUDA, Jan. Bez emocí to jde správně. In: LinkedIn [online]. 24. 3. 2020 [cit. 5. 8. 2020]. Dostupné $\quad$ z: https://www.linkedin.com/pulse/bez-emoc\%C3\%AD-jde-spr\%C3\%A1vn \%C4\%9B-jan-klouda.

39 Bod I písm. b) mimořádného opatření MZDR 12398/2020-1/MIN/KAN.

${ }^{40}$ Chytrá karanténa - Aktuální informace o COVID-19.; DPIA vzpomínkových map, s. 4.

${ }^{41}$ DPIA vzpomínkových map, s. 10.

${ }^{42}$ Právní základ podle čl. 6 odst. 1 písm. c) a e) GDPR.

${ }^{43}$ Právní základ podle čl. 9 odst. 2 písm. g) a i) GDPR; srov. DPIA vzpomínkových map, s. 4.

${ }^{44}$ Ibid., s. 4 a 11.

${ }^{45}$ Ibid., s. 16.

${ }^{46}$ Ibid., s. 11 a 12. 
Následně došlo ke kompletnímu převedení provozu na stát a soukromé společnosti jako Keboole se tedy už na zpracování osobních údajů nepodíle$1 y{ }^{47}$

\subsubsection{MOBILNÍ APLIKACE EROUŠKA}

Aplikace eRouška umožňovala prostřednictvím technologie Bluetooth automatický záznam identifikátorů mobilních telefonů osob, v jejichž blízkosti se majitel telefonu nacházel. Pokud byla následně jedna $\mathrm{z}$ těchto osob testována pozitivně, měla možnost poskytnout tuto informaci ostatním a tím je upozornit na potenciální nakažení.

Aplikace zaznamenávala ID telefonů mající tutéž aplikaci společně se sílou signálu pro odhad vzájemné vzdálenosti. ${ }^{48}$ Údaje, které se o „setkání“ ukládaly, byly náhodný identifikační řetězec znaků identifikující protější telefon (navíc každou hodinu obměňovaný) ${ }^{49}$, časové razítko a síla signálu Bluetooth. ${ }^{50}$ Všechny informace byly uloženy lokálně na telefonu, a to po dobu pěti dní od vytvoření. ${ }^{51}$ Vznikla tak decentralizovaná databáze. ${ }^{52}$ Centrálně byl uložen náhodný identifikační řetězec spojený s telefonním číslem uživatele pro případný kontakt při hrozbě nakažení - dohromady spojit konkrétní osobu a její identifikátor tak mohla pouze KHS. ${ }^{53}$

\footnotetext{
${ }^{47}$ Provoz chytré karantény nyní zajištuje Národní agentura pro komunikační a informační technologie, s. p. na základě smlouvy s Ministerstvem zdravotnictví ČR. Smlouva je dostupná z https://smlouvy.gov.cz/smlouva/13430376.

${ }^{48}$ Souhrnná DPIA eRouška v. 0.2, s. 3 a 4. Po omezený čas k dispozici z: https://cutt.ly/blhBHUh. DPIA eRoušky bylo získané na základě žádosti autora podle zákona č. 106/1999 Sb., o svobodném př́stupu $\mathrm{k}$ informacím. Odpověd povinného subjektu je dostupná $\mathrm{z}$ : https://www.mzcr.cz/wp-content/uploads/2020/08/239_2020_A.pdf.

49 JANN, Ole, Pavel KOCOUREK a Jakub STEINER. Využití technologie Bluetooth pro trasování šiření covid-19 [online]. Institut pro demokracii a ekonomickou analýzu, 2020, s. 7 [cit. 5. 8. 2020]. Dostupné z: https://idea.cerge-ei.cz/files/ IDEA_Trasovani_covid19_duben2020_14.pdf

${ }^{50}$ Ochrana soukromí a cookies eRoušky. In: eRouška [online] [cit. 08.05.2020]. Dostupné z: https://erouska.cz/podminky-pouzivani; a DPIA eRouska v. 0.2, s. 12. Zapsaná informace vypadala např. takto: „31.3.2020 od 12:15 do 13:15 byla ve vaší blízkosti aplikace s identifikátorem ID 29091" (viz Ibid., s. 5.).

${ }^{51}$ DPIA eRouška v. 0.2, s. 4.

52 JANN, Ole, Pavel KOCOUREK a Jakub STEINER. Využití technologie Bluetooth pro trasování šîrení covid-19, s. 4.
} 
Nezávislé instituce potvrdily, že aplikace odesílala seznam zaznamenaných identifikátorů pouze s výslovným souhlasem uživatele a nesbírala polohové údaje. ${ }^{54}$

Identifikované právní tituly pro zpracování byly veřejný zájem ${ }^{55}$ a souhlas. ${ }^{56}$

Poskytnuté telefonní číslo zůstalo uloženo na serveru i po odinstalování aplikace, spolu s identifikátorem uživatele a značkou a modelem telefonu, na kterém aplikace byla. ${ }^{57}$ Přesná retenční doba těchto údajů nebyla určena. ${ }^{58}$

Správcem osobních údajů bylo Ministerstvo zdravotnictví ČR, zpracovateli společnost Keboole, platforma Google Cloud a Firebase. ${ }^{59}$ Google Cloud Platform ve zpracování vystupovalo z důvodu hostování dat na tamních serverech. $^{60}$

\subsubsection{DALŠÍ RELEVANTNÍ INFORMACE}

Je také na místě upozornit, že v Česku byl v souvislosti s koronavirem aplikovatelný i obecný právní rámec o data retention. ${ }^{61} \mathrm{~K}$ metadatům komunikace uživatelů se tak mohly dostat orgány činné v trestním řízení v rámci vyšetřování trestných činů spáchaných za nouzového stavu, a to i v přímé souvislosti s koronavirem. ${ }^{62}$ Protože tuto původně možnou širokou aplikovatelnost lze nyní považovat za omezenou ${ }^{63}$ a navíc úprava data retention

\footnotetext{
${ }^{53}$ Ochrana soukromí a cookies eRoušky.; DPIA eRouška v. 0.2, s. 5 a 6. Mimo uvedené údaje schraňovala aplikace i další údaje, které jsou pro zde činěné úvahy irelevantní. Konkrétně šlo o typ telefonu, typ OS, výrobce zařízení, verzi systému, jazykovou lokalizaci a různé tokeny (srov. Ibid., s. 13 a 14.).

54 Potvrzení jsou dostupná z: https://erouska.cz/downloads/cvut3.pdf; https://erouska.cz/ downloads/cvut2.pdf; a https://erouska.cz/downloads/cvut.pdf.

55 Právní titul podle čl. 6 odst. 1 písm. e) a čl. 9 odst. 2 písm. h) a i) GDPR; DPIA eRouška $v$. 0.2, s. 15.

${ }^{56}$ Právní titul podle čl. 6 odst. 1 písm. a) a čl. 9 odst. 2 písm. a) GDPR; Ibid., s. 16.

57 Ibid., s. 13.

58 Ibid., s. 21.

59 Ibid., s. 15.

${ }^{60}$ Ibid., s. 7.

${ }^{61}$ Ustanovení § 97 odst. 4 a 3 ElKomČR.
} 
je v současné době shledána ústavně konformní, ${ }^{64}$ nebude zde tomuto tématu dále věnován prostor.

\section{SLOVENSKÁ REPUBLIKA}

I slovenská chytrá karanténa se skládala ze dvou částí. První byla mobilní aplikace eKaranténa a druhá pak nová oprávnění Úradu verejného zdravotníctva SR („ÚVZ“) vyžadovat údaje od mobilních operátorů. Podle vyjádření vlády SR a ÚVZ v řízení před Ústavním soudem SR byla plánována i obdoba vzpomínkových map. ${ }^{65}$ O zavedení tohoto systému ovšem nejsou dostupné jakékoliv informace.

I v případě slovenského řešení jsem žádal o poskytnutí relevantních DPIA, nicméně zatím neúspěšně. ${ }^{66}$ Zde poskytnutý obraz je tak získaný téměř výhradně z veřejných zdrojů.

\subsection{MOBILNÍ APLIKACE EKARANTÉNA}

Na jaře 2020 byla povinná karanténa po překročení slovenských státních hranic v zásadě vykonávána v tzv. „státní karanténě“, tzn. v některé z k tomuto účelu vyhrazené budově, a to až do okamžiku prokázání se negativním testem. ${ }^{67}$ Alternativou byla tzv. „smart karanténa“, která probíhala v obydlí osoby za využití mobilní aplikace eKaranténa.

Aby mohla osoba vykonat izolaci v domácí smart karanténě, musela udělit souhlas. ${ }^{68}$ Doma pak byla prostřednictvím mobilní aplikace hlídána, přičemž její využívání bylo povinné. ${ }^{69}$ Kontrola dodržování nařízené karantény prostřednictvím aplikace probíhala jednak skrze záznam polohy telefonu s pomocí technologie GPS a jednak skrze povinnost vyfotit na vyzvání

${ }^{62}$ Ustanovení $\S 88$ a odst. 1 zákona č. 141/1961 Sb., trestní řád. Může se jednat např. o trestný čin šîření nakažlivé lidské nemoci (§ 152 odst. 2 písm. b) zákona č. 40/2009 Sb., trestní zákoník), krádež (§ 205 odst. 4 písm. b) tamtéž), podvod (§ 209 odst. 4 písm. c) tamtéž) nebo šîření poplašné zprávy (§ 357 odst. 4 písm. a) tamtéž).

${ }^{63}$ Pro období nouzového stavu srov. přiměřeně rozsudek Nejvyššího soudu ze dne 16. 3. 2021, sp. zn. 15 Tdo 110/2021. Pro období tzv. „pandemické pohotovosti“ pak srov. § 14 zákona č. 94/2021 Sb., o mimořádných opatřeních při epidemii onemocnění COVID19.

${ }^{64}$ Nález Ústavního soudu ČR ze dne 14. 5. 2019, sp. zn. Pl. ÚS 45/17.

${ }^{65}$ Usnesení Ústavního soudu SR ze dne 13. 3. 2020, č. j. PL. ÚS 13/2020-103, odst. 73-74. 
selfie, která se automaticky porovnala s fotografií nahranou do databáze při registraci. ${ }^{70} \mathrm{~K}$ tomu stanovil zákon související povinnosti (povolit geolokaci, umožnit aktualizace, uložit fotografii pro porovnání apod.). ${ }^{71}$

Porovnání polohy telefonu s oblastí, kde osoba měla vykonávat karanténu a porovnání pořizovaných selfie, se provádělo pouze na koncovém zařízení. $^{72}$ Tyto údaje poté byly vymazány do 30 dní od jejich vzniku. ${ }^{73}$

Aplikace eKaranténa vedle toho taktéž umožňovala, obdobně jako česká eRouška, zaznamenávání kontaktu s jinými osobami prostřednictvím tech-

${ }^{66}$ Žádost o poskytnutí tří relevantních DPIA podle zákona č. 211/200 Z. z., o slobode informácií („SlInf“) byla ÚVZ odmítnuta rozhodnutím ze dne 16. 7. 2020, č. RK/5554/20 (po omezený čas dostupné z https://cutt.ly/VkP4Ogz) z důvodu, že DPIA aplikace eKaranténa je obchodním tajemstvím ( $§ 10$ odst. 1 SlInf), byla jí odevzdána třetí osobou, která se zveřejněním nesouhlasí (§ 11 odst. 1 písm. a) SlInf) a zároveň by došlo k porušení duševního vlastnictví (písm. c) tamtéž). Ministerstvo zdravotnictví SR jako odvolací orgán rozhodnutím ze dne 24. 9. 2020, č. S15047-2020-ONAPP-2 (po omezený čas dostupné z https://cutt.ly/UkP7d4z) prvostupňové rozhodnutí zrušilo jako nepřezkoumatelné a věc vrátilo $\mathrm{k}$ dalšímu řízení. ÚVZ následně žádost opět odmítl rozhodnutím ze dne 29. 10. 2020, č. RK/7217/2020 (po omezený čas dostupné $\mathrm{z}$ https://cutt.ly/GkP5q3U), tentokrát protože by poskytnutí všech DPIA bylo v rozporu s právem EU (zejména GDPR) (§ 11 odst. 1 písm. g) SlInf) a protože jde o dokumenty, které obsahují informace využitelné na plánování a vykonání narušení objektů zvláštní důležitosti (písm. i) tamtéž). Ani tomuto odůvodnění odvolací orgán nepřisvědčil a rozhodnutím ze dne 24. 11. 2020, č. S17812-2020-ONAPP-2 (po omezený čas dostupné $\mathrm{z}$ https://cutt.ly/CkP6fYo) věc vrátil k dalšímu řízení. Následně ÚVZ vydal dne 30. 12. 2020 další odmítavé rozhodnutí č. OK/ 10825/2020 (po omezený čas dostupné $\mathrm{z}$ https://cutt.ly/ckAqPmc), podle kterého část požadovaných DPIA nebyla zpracována a DPIA eKarantény je obchodní tajemství a duševní vlastnictví třetí osoby (bylo vypracováno advokátní kanceláří Dagital Legal, s.r.o.) (§ 10 odst. 1 SlInf a § 11 odst. 1 písm. c) SlInf), bylo vypracováno zdarma, ÚVZ nedisponuje DPIA fyzicky (má ho pouze ona advokátní kancelář) a ÚVZ by vznikla škoda (protože za jakékoliv zpřístupnění je sjednána smluvní pokuta 50.000 EUR). Toto rozhodnutí bylo rozhodnutím odvolacího orgánu ze dne 23. 2. 2021, č. S11089-2021-0ddNAPP-2 (po omezený čas dostupné $\mathrm{z}$ https://cutt.ly/nl2sTF9) opět zrušeno jako nepřezkoumatelné. Př́ípisem ze dne 23. 3. 2021 byla část žádosti (ve vztahu k DPIA aplikace eKarantény) postoupena podle $\S 15$ odst. 1 SlInf Úřadu na ochranu osobních údajů SR, který tuto část žádosti odmítl rozhodnutím ze dne 1. 4. 2021, č. 00157/2021-Ku/2 (po omezený čas dostupné z https://cutt.ly/db0SnDV), nebot jde o dokument získaný v průběhu kontroly (§ 11 odst. 1 písm. h) SlInf). Následně ÚVZ vydal dne 22. 3. 2021 rozhodnutí č. OK/2363/2021 (po omezený čas dostupné z https://cutt.ly/4x0uRkE), kterým celou žádost opět odmítnul, nebot DPIA aplikace eKaranténa nemá $\mathrm{v}$ jakékoliv podobě $\mathrm{k}$ dispozici a DPIA předávání osobních údajů podle $\S 63$ odst. 18 až 20 nebylo zpracováno. Odvolací rozhodnutí Ministerstva zdravotnictví SR ze dne 12. 5. 2021, č. S14938-2021-OddNAPP-2 (po omezený čas dostupné $\mathrm{z}$ https://cutt.ly/ib0P8Fy) napadené rozhodnutí znovu zrušilo a věc vrátilo $\mathrm{k}$ dalšímu řízení. K DPIA aplikace eKaranténa konstatovalo, že postoupí-li povinná osoba část žádosti, je nezákonným postupem, pokud ve stejné části žádost zároveň odmítne. Ve vztahu ke zbylým částem bylo rozhodnutí nepřezkoumatelné. Ve vztahu k DPIA aplikace eKaranténa 
nologie Bluetooth. ${ }^{74}$ Zaslání oznámení o možném kontaktu s nakaženou osobou mohlo být provedeno jen s jejím souhlasem. ${ }^{75}$

V současné době již není třeba aplikace eKaranténa při vstupu na Slovensko. Původní opatření ÚVZ, kterým byla tato povinnost stanovena, bylo k 10. 6. 2020 zrušeno a povinnost využívat aplikaci eKaranténa nebyla znovu stanovena. ${ }^{76}$ Nyní již aplikace eKaranténa není dostupná ani ke stažení. 77

\subsection{PŘEDÁVÁNÍ DAT MOBILNÍMI OPERÁTORY}

Slovenský zákonodárce na pandemii také reagoval přijetím zákona č. $62 / 2020$ Z. Z., o niektorých mimoriadnych opatreniach v súvislosti so šírením nebezpečnej nákazlivej l'udskej choroby COVID-19 a v justícii. Tímto zákonem byly do § 63 ElKomSR, vloženy odstavce 18 až 20, které přikázaly mobilním operátorům poskytovat ÚVZ údaje o svých zákaznících. Na základě návrhu poslanců Národní rady SR pozastavil Ústavní soud SR účinnost části uvedeného ustanovení. ${ }^{78}$ Slovenský zákonodárce

jsem tak dne 19. 5. 2021 podal novou žádost, která nebyla zatím vyřízena.

67 Opatrenie ÚVZ pri ohrození verejného zdravia - eKaranténa ze dne 22. 5. 2020, sp. zn. OLP/4311/2020.

68 Ustanovení § 60a odst. 3 zákona č. 355/2007 Z.z., o ochrane, podpore a rozvoji verejného zdravia („OchrZdrSR“).

69 Ustanovení § 51 odst. 1 písm. f) OchrZdrSR.

70 Smart karanténa - najčastejšie otázky ohl’adne karantény v domácej izolácii s využitím aplikácie eKaranténa. In: Korona.gov.sk [online] [cit. 04.10.2020]. Dostupné z: https://korona.gov.sk/najcastejsie-otazky/ekarantena/

71 Ustanovení § 60a odst. 4 OchrZdrSR.

72 Smart karanténa - najčastejšie otázky ohl'adne karantény $v$ domácej izolácii s využitím aplikácie eKaranténa.

73 Ustanovení § 60d odst. 4 OchrZdrSR.

74 Ustanovení § 60a odst. 8 písm. d) OchrZdrSR.

75 Ustanovení $\S 60$ b odst. 3 OchrZdrSR.

76 Opatrenie ÚVZ pri ohrození verejného zdravia - domáca izolácia, zrušenie štátnej karantény ze dne 9. 6. 2020, sp. zn. OLP/4739/2020.

77 Aplikace byly původně dostupné na těchto adresách: https://play.google.com/store/apps/ details?id=sk.nczi.ekarantena a https://apps.apple.com/sk/app/ekarantena-slovensko/ id1513127897. 
jednal rychle, a již o dva dny později citované ustanovení novelizoval, ${ }^{79}$ pročež Ústavní soud SR řízení zastavil. ${ }^{80} \mathrm{~V}$ současné době zní relevantní část tohoto ustanovení (včetně vyznačení zmíněné novelizace - prešraté odebráno, podtržené přidáno) takto:

(18) Údaje, ktoré sú predmetom telekomunikačného tajomstva podl'a odseku 1 písm. b) a d) spolu s informáciou o čase vzniku lokalizačného údaju podnik $v$ čase mimoriadnej situácie ${ }^{46 d)}$ alebo núdzového stavu ${ }^{46 e)}{ }^{v}$ zdravotníctve, a to $v$ prícinnej súvislosti so vznikom pandémie ${ }^{468}$ alebo širením nebezpečnej nákazlivej l’udskej choroby a po prijatí zodpovedajúcich technických a organizačných opatrení na ochranu súkromia a osobných údajov $[$ [...]

b) spracúva na účel identifikácie príjemcov správ, ktorým je potrebné oznámit’ osobitné opatrenia [ÚVZ] $]^{46 f)} v$ záujme ochrany života a zdravia,

c) spracúva výlučne $v$ rozsahu potrebnom na identifikáciu pohybu dotknutého uživatel’a $v$ záujme ochrany života a zdravia.

(19) Údaje spracúvané podl'a odseku 18 podnik poskytuje [ÚVZ] na základe odôvodnenej písomnej žiadosti a s pisomným súhlasom alebo inak hodnoverne preukázatelným súhlasom dotknutého uživatel'a. [...]

(20) [ÚVZ] môže po prijatí zodpovedajúcich technických a organizačných opatrení na ochranu súkromia a osobných údajov údaje spracúvané podl'a odseku 18 zbierat', spracúvat' a uchovávat počas trvania mimoriadnej situácie alebo

78 Ústavní soud SR pozastavil účinnost § 62 odst. 18 písm. c) ElKomSR a také § 63 odst. 19 a 20 ElKomSR v rozsahu, v jakém se na ně vztahuje $\S 63$ odst. 18 písm. b) a c) téhož předpisu; srov. usnesení Ústavního soudu SR č. j. PL. ÚS 13/2020-103.

79 Zákon č. 119/2020 Z.z., ktorým sa mení a dopĺña zákon č. 355/2007 Z.z. o ochrane, podpore a rozvoji verejného zdravia a o zmene a doplnení niektorých zákonov v znení neskorších predpisov a ktorým sa mení a dopíňa zákon č. 351/2011 Z.z. o elektronických komunikáciách v znení neskorších predpisov.

${ }^{80}$ Usnesení Ústavního soudu SR ze dne 27. 3. 2020, č. j. PL. ÚS 13/2020-18. 
núdzového stavu $v$ zdravotníctve, najdlhšie do 31. decembra 2020. Údaje podl'a odseku 18 musí [ÚVZ] bezodkladne zničit' akonáhle pominie dôvod na ich spracúvanie; o zničení údajov [ÚVZ] bezodkladne písomne informuje dotknutého uživatel'a, pričom uvedie údaje, ktoré o ňom spracúval. [ÚVZ] podá najneskôr do 31. januára 2021 Ústavnoprávnemu výboru Národnej rady Slovenskej republiky správu o zákonnosti spracúvania údajov podl'a odseku 18; pôsobnost' Úradu na ochranu osobných údajov Slovenskej republiky tým nie je dotknutá.

Údaje, na které citované ustanovení dopadlo, byly podle $\S 63$ odst. 1 písm. b) a d) ElKomSR telefonní číslo, označení osoby včetně adresy trvalého pobytu nebo sídla obou stran komunikace a lokalizační údaje.

Vedle této úpravy ještě zákonodárce později přijal druhou novelu ElKomSR, ${ }^{81}$ kterým vznikl $\S 42$ odst. 5 a $\S 63$ odst. 21 tohoto předpisu. Ty umožnily ÚVZ získat telefonní číslo všech osob, kterým byla zaslána varovná textová zpráva týkající se ochrany osob před hrozícím nebezpečím a opatření při ochraně života a zdraví. Podle důvodové zprávy má tato možnost sloužit státu $\mathrm{k}$ identifikaci osob, které se vrací z tzv. „červených krajin“, v důsledku čehož musí při návratu na Slovensko nastoupit do karantény. I takové poskytování údajů představuje průlom telekomunikačního tajemství. $^{82}$

Ke zpracování lokalizačních údajů, pro určení relevantních osob nacházejících se v zahraničí, docházelo na straně operátorů bez souhlasu či informování. ÚVZ poté mohl údaje zpracovávat maximálně 60 dní.

Prezidentka přijetí zákona vetovala, byla ovšem Národní radou SR přehlasována. ${ }^{83}$

81 Zákon č. 242/2020 Z. z., ktorým sa mení a dopíňa zákon č. 351/2011 Z. z. o elektronických komunikáciách $\mathrm{v}$ znení neskorších predpisov.

82 Podle $\S 63$ odst. 1 ElKomSR se do telekomunikačního tajemství řadí mj. telefonní číslo a lokalizační údaje. 


\subsection{SROVNÁNÍ PROVEDENÝCH OPATŘENÍ}

Už na první pohled je znát rozdílný přístup $\mathrm{k}$ využití technologie $\mathrm{v}$ rámci strategie boje proti nákaze koronavirem. Zatímco $\mathrm{v}$ českém případě se od začátku projektu počítalo s využitím souhlasu pro předávání osobních údajů státu, na Slovensku byla první verze legislativy nastavena bez souhlasu, který byl přidán až po rychlém zásahu Ústavního soudu SR.

Dalším znatelným rozdílem zde je, že zatímco v České republice se u chytré karantény spoléhalo na podzákonné předpisy, v případě Slovenska existovala opora přímo v zákonech.

Diametrálně odlišný přistup je i v aplikacích. Česká aplikace eRouška fungovala pouze pro zaznamenání kontaktu s jinými osobami při pohybu na veřejných prostranstvích za využití technologie Bluetooth a pro případné trasování kontaktů nakaženého, zatímco její slovenský protějšek eKaranténa byl primárně nastaven tak, že hlídal dodržování nařízené karantény skrze připojení $\mathrm{k}$ internetu, polohové služby a selfie uživatele.

Již nyní je zřejmé, že průběh hodnocení bude $\mathrm{v}$ nastíněných případech rozdílný. Přijatá opatření jsou od sebe odlišná, stejně jako okruh údajů dostupných veřejné moci.

\section{ANALÝZA ČESKÉHO ŘEŠENÍ}

\subsection{TECHNICKÉ ŘEŠENÍ APLIKACE EROUŠKA}

Jak bylo popsáno výše, aplikace eRouška zaznamenávala kontakt s ostatními osobami skrze technologii Bluetooth. $\mathrm{V}$ rámci jejího fungování nebyly nikdy využity geolokační údaje. Tento postup je zcela v souladu s doporu-

83 ŠTRAHA, Štěpán a Martina RIEVAJOVÁ. UPDATE: Slovenský Úrad verejného zdravotníctva získal prístup $k$ vašim telefónnym číslam, aj ked’ mu prezidentka dala stopku [online]. 2020 [cit. 4. 10. 2020]. Dostupné $\quad z:$ https://www.havelpartners.blog/blog/slovensky-uradverejneho-zdravotnictva-nebude-mat-zatial-pristup-k-vasim-telefonnym-cislam-prezidentkamu-dala-stopku/157 
čeními Evropské komise, ${ }^{84}$ Evropského sboru pro ochranu osobních údajü ${ }^{85}$ i odborné veřejnosti ${ }^{86}$ ohledně minimalizace zásahu do soukromí uživatelů.

Nemůže být pochyb ani o tom, že se jedná o technologii vhodnější z hlediska zaznamenávání kontaktu. Byla totiž zaznamenávána faktická vzdálenost mezi telefony (skrze sílu signálu Bluetooth) a nikoliv jejich poloha na mapě. Omezila se tak možnost zaznamenání kontaktu tam, kde podle geolokačních údajů byly osoby $\mathrm{v}$ určité blízkosti (např. osoba $\mathrm{v}$ přízemním bytě s osobou bydlící v podkroví stejného domu), a zachytily se pouze tam, kde skutečně došlo k přiblížení osob.

Problematickým aspektem aplikace eRouška mohla být vytvořená centrální databáze telefonních čísel. Číslo musel uživatel zadat při registraci do aplikace. V centrální databázi pak telefonní číslo bylo propojené s jednotlivými identifikačními kódy osoby, čemuž měli přístup pověrení pracovníci KHS.

Telefonní číslo (a tedy celá centralizovaná databáze) přitom nebylo pro funkčnost systému zcela nezbytné. Informaci o možném nakažení je totiž možné doručovat, bez zprostředkování KHS, automaticky prostřednictvím notifikací. $^{87}$

Přesně tímto směrem se vydala druhá verze eRoušky vydaná na konci letních prázdnin 2020 a fungující dodnes. Změna způsobu fungování aplikace umožnila odstranit všechny osobní údaje z jejího provozu - Ministerstvo zdravotnictví ČR ani KHS tak zásadně nemohou ztotožnit jednotlivé

${ }^{84}$ Sdělení Komise, Pokyny k aplikacím podporujícím boj proti pandemii COVID-19 ve vztahu k ochraně údajů, s. 6.

${ }^{85}$ Dopis předsedy Evropského sboru pro ochranu osobních údajů O. Micolovi [online]. Evropská sbor pro ochranu osobních údajů, , s. 2 [cit. 1. 9. 2020]. Dostupné z: https://edpb.europa.eu/sites/edpb/files/files/file1/edpbletterecadvisecodiv-appguidance_final.pdf

${ }^{86}$ COUNCIL OF EUROPE DIRECTORATE GENERAL HUMAN RIGHTS AND RULE OF LAW. AI Breakfasts: Covid-19 - Myths and realities of tracking applications [online], č. 0:12:00 [cit. 18. 5. 2020]. Dostupné z: https://www.youtube.com/watch?v=19d3B6AuvdI

87 DOČEKAL, Daniel. Jak na iPhonech funguje trasování nákazy koronavirem (COVID-19 Exposure Tracing)? In: Lupa.cz [online]. 21. 5. 2020 [cit. 1. 9. 2020]. Dostupné z: https:// www.lupa.cz/clanky/jak-na-iphonech-funguje-trasovani-nakazy-koronavirem-covid-19-exposure-tracing/ 
uživatele. ${ }^{88} \mathrm{~V}$ současné době probíhá sběr identifikátorů na stejném principu jako v předchozí verzi ${ }^{89}$ ale změnil se způsob nakládání s nimi.

Vlastní identifikátory mohou být po prokázání nakažení odeslány na servery aplikace. Podmínkou odeslání je ověření kódem z verifikační zprávy SMS, kterou odesílá systém bud’ automaticky anebo na pokyn pracovníka KHS. Zabraňuje se tak nekontrolovatelnému nahrávání identifikátorů osob, které nejsou nakaženy. Ze serveru aplikace si identifikátory nakažených osob mohou ostatní uživatelé stáhnout po dobu 14 dní. Údaje jsou pak lokálně vyhodnocovány a pokud aplikace identifikuje rizikový kontakt, lokálně vygeneruje notifikaci. ${ }^{90} \mathrm{~V}$ celém tomto procesu není nakažená osoba identifikována. ${ }^{91}$

\subsection{ABSENTUJÍCÍ PRÁVNÍ NORMY}

Pro zpracování osobních údajů v první verzi eRoušky chyběla, dle mého názoru, v právním řádu dostatečná a transparentní opora. Ministerstvo zdravotnictví ČR se v DPIA eRoušky v. 0.2 odvolávalo na zpracování na základě veřejného zájmu a pro zvláštní kategorii osobních údajů uvedlo souhlas podpořený jinými tituly. Více se k právnímu základu v DPIA eRoušky v. 0.2 již neuvádí. Ačkoliv využití titulu veřejného zájmu $\mathrm{v}$ tomto př́ípadě není zcela zcestné, domnívám se, že zpracování těchto údajů by mělo být založeno na jasné právní normě, a tedy titulu plnění právní povinnosti. Ke stejnému závěru se přiklání i pokyny Evropské komise. ${ }^{92}$

$\mathrm{Na}$ druhou stranu byl rozměr tohoto problému relativizován dobrovolností poskytnutí údajů. Jak instalace aplikace, tak i následné odeslání vlastních identifikátorů bylo zcela na vůli jednotlivce. Právní řád neposkytoval možnosti donucení. I při zachování současného systému

${ }^{88}$ DPIA eRouška 2.0, v. 6 ze dne 4. 2. 2021, s. 32. Po omezený čas k dispozici z: https://cutt.ly/llhNjjK. DPIA eRouška 2.0 bylo získané na základě žádosti autora podle zákona č. 106/1999 Sb., o svobodném přístupu k informacím. Odpověd' povinného subjektu je dostupná z: https://www.mzcr.cz/wp-content/uploads/2021/02/56-A.pdf.

${ }^{89}$ Ibid., s. 15.

90 Ibid., s. 19.

${ }^{91}$ Ibid., s. 16 a 17.

92 Sdělení Komise Pokyny k aplikacím podporujícím boj proti pandemii COVID-19 ve vztahu k ochraně údajů, s. 5. 
dobrovolnosti by nicméně založení zpracování na plnění právní povinnosti fungování eRoušky více zprůhlednilo. Zároveň by mohly být nastaveny zcela jasné zákonné záruky proti zneužití takových údajů, jako například doba uložení nebo zákaz zpracování pro jiné účely. Odhlédneme-li od částečně jiné povahy slovenské aplikace eKaranténa, tak její právní zakotvení by mohlo být př́kladem.

I tato výtka s dalším vývojem částečně odpadla. Za prvé je to $\mathrm{z}$ důvodu vynechání osobních údajů $\mathrm{z}$ řešení eRoušky ${ }^{93}$ a za druhé kvưli přijetí relevantní právní úpravy. ${ }^{94}$ Té je ovšem možné vytknout nedostatečnou konkrétnost, nebot pouze zmocňuje Ministerstvo zdravotnictví ČR ke zřízení aplikace a zakotvuje dobrovolné užívání. Stále tak chybí jasné mantinely zmiňované výše, jako je např. maximální doba zpracování.

Ze dvou probíraných částí chytré karantény je nicméně potřeba jasného zákonného základu zřetelně větší u tvorby vzpomínkových map. To je odůvodněno obsahem zpracovávaných osobních údajů (bankovní a telekomunikační tajemství). DPIA vzpomínkových map se mj. odvolává na plnění zákonné povinnosti (konkrétně § 62a odst. 1 a 67 OchrZdrČR). Tyto ustanovení nicméně nejsou dle mého názoru dostatečně konkrétní a přesná. Aby mohl správce založit zpracování na titulu plnění právní povinnosti, musí mu právní řád přímo něco přikazovat. ${ }^{95}$

Ustanovení § 62a odst. 1 OchrZdrČR pouze opravňuje př́slušné správní orgány $\mathrm{k}$ provádění epidemiologických šetření. Existuje tedy diskrece orgánu co do způsobu provedení a titul plnění zákonné povinnosti nelze využít. Ustanovení § 67 OchrZdrČR potom sice stanovuje povinnost rozhodnout o protiepidemických opatřeních, ale tuto povinnost dále nikterak nespecifikuje.

93 Pro verzi 2.0 byly identifikovány jako právní tituly čl. 6 odst. 1 písm. e) a čl. 9 odst. 2 písm. i) GDPR (zpracování ve veřejném zájmu) a pro mezinárodní spolupráci pak slouží souhlas. Srov. DPIA eRouška 2.0, s. 32 a 33.

94 Ustanovení § 62 odst. 2 až 5 OchrZdrČR, které byly vloženy zákonem č. 94/2021 Sb., o mimořádných opatřeních při epidemii onemocnění COVID-19.

95 NULÍČEK, Michal et al. GDPR - obecné nařizzení o ochraně osobních údajů. Wolters Kluwer, 2018, kap. čl. 6 odst. 1 písm. e). 
Povinnost předat osobní údaje a podrobnosti zpracování osobních údajů u vzpomínkových map stanovuje mimořádné opatření. To se odvolává na § 69 odst. 1 písm. i) OchVeřZdČR, který umožňuje vydat „zákaz nebo nař́zení dalši určité činnosti $k$ likvidaci epidemie nebo nebezpeči jejího vzniku." $\mathrm{Z}$ tohoto ale vyvstávají dva problémy. Zaprvé dochází k omezení základního práva na základě podzákonného předpisu. Oproti tomu ale platí, že meze základních práv je možné podle čl. 4 odst. 2 Listiny základních práv a svobod omezit pouze zákonem. ${ }^{96}$ Existuje zde tak evidentní rozpor. Zadruhé lze zpochybnit pravomoc Ministerstva zdravotnictví ČR vůbec takový předpis vydat. Jakkoliv citované ustanovení představuje zbytkovou kategorii jeho pravomocí při epidemii, nejde o kategorii bezbřehou. Nejvyšší správní soud ČR zde dovodil povinnost výkladu „stejného druhu“ - tzn. při jejím výkladu lze dovodit pouze takové pravomoci, které odpovídají ostatním v tomto výčtu. ${ }^{97}$ Zkoumané mimořádné opatření tak můžeme považovat za vydané ultra vires. Jako pojistku proti svévolnému zasahování státu do soukromí lze nicméně považovat nutnost souhlasu pro poskytnutí údajů od bank a mobilních operátorů.

Kritickým problémem zde byla (a stále je) nepřipravenost zvláštních právních předpisů na takovou situaci. Konkrétně jde o ElKomČR a § 38 zákona č. 21/1992 Sb., o bankách. Ani jeden totiž nepamatuje na jakoukoliv možnost předávání dat státu za této situace nebo na možnost zpracování údajů chráněných bankovním či telefonním tajemstvím pro tyto účely. Nedomnívám se, že předání osobních údajů bylo zcela v rozporu se sektorovou úpravou, ale určitě se pohybuje v šedé zóně. Takové řešení je ale $\mathrm{v}$ případě takto širokého omezování základních práv značně neštastné.

Závěrem bych chtěl také upozornit na fakt, že podle zjištěných informací došlo již v září 2020 k ukončení využívání dat od bank, ${ }^{98}$ ale nikoliv již k navazující úpravě mimořádného opatření, které stanovuje rámec pro přenos či informační povinnosti správce. O konci využívání bankovních dat

96 Obdobně pak srov. usnesení Ústavního soudu SR č. j. PL. ÚS 13/2020-103, odst. 100.

97 Rozsudek Nejvyššího správního soudu ze dne 26. 2. 2021, č. j. 6 As 114/2020-63, zejm. odst. 142 až 144.

98 Tato informace byla sdělena autorovi v průběhu telefonátu s pověřencem pro ochranu osobních údajů Ministerstva zdravotnictví ČR dne 15. 9. 2020. 
se nadto nedají najít ani žádné oficiální publikované informace. Postup správce se tak stal matoucím a netransparentním.

Vzhledem k tomu, za jak důležitý prvek boje proti koronaviru byla celá chytrá karanténa považována, ${ }^{99}$ jsem toho názoru, že jí měl být v rámci zákonodárství poskytnut větší prostor. ${ }^{100}$ Zejména tedy vydefinování účelů v zákoně, spolu s poskytnutím záruk proti zneužití získaných údajů. Tato kritika ale neznamená, že by soukromí občanů anebo principy GDPR byly nějakým způsobem hrubě pošlapávány. Ono zákonné ukotvení by mělo sloužit pro zajištění právní jistoty a transparentnosti zpracování osobních údajů.

Za naplňující vytyčené nicméně nemůže být považován navrhovaný nový § 89a ElKomČR. Ten by měl umožnit hygienickým stanicím žádat po mobilních operátorech údaje o místě pobytu osoby s infekčním onemocněním v posledních třech týdnech, a to bez jejího souhlasu. Po poskytnutí má být osoba o tomto postupu notifikována. Tato nová povinnost je $\mathrm{v}$ důvodové zprávě pouze stroze odůvodněna potřebou efektivního trasování kontaktů. ${ }^{101}$ Jde totiž o úpravu, která není potřebně kvalitní, podrobná, řádně odůvodněna a zajištující dostatečnou kontrolu. ${ }^{102}$

99 Za všechny odkazuji na Velikonoční projev Předsedy vlády ČR dostupný z: https:// www.vlada.cz/cz/clenove-vlady/premier/projevy/velikonocni-projev-predsedy-vlady$180961 /$.

${ }^{100}$ Projednávané a schválené sněmovní tisky jsou důkazem toho, že projektu chytré karantény nebyl věnován jakýkoliv legislativní prostor. Jejich seznam je dostupný z https:// www.psp.cz/sqw/tisky.sqw? $\operatorname{str}=13 \& \mathrm{O}=8 \& \mathrm{PT}=\mathrm{K} \& \mathrm{~N}=1 \& \mathrm{~F}=\mathrm{N} \& \mathrm{D}=1,2,16 \& \mathrm{U}=6,11 \& \mathrm{RA}=20$.

${ }^{101}$ Materiál č. j. OVA 971/20. In: Portál Aplikace ODok [online] [cit. 22. 3. 2021]. Dostupné z: https://apps.odok.cz/veklep-detail?pid = KORNBSNH56J5

${ }^{102}$ K tomu blíže srov. RP: Návrh zákona o elektronických komunikacích je protiústavní. In: Advokátní deník [online]. 19.1. 2021 [cit. 22.03.2021]. Dostupné z: https://advokatnidenik.cz/2021/01/19/rozumne-pravo-navrh-zakona-o-povinnem-predavani-dat-operatory-je-protiustavni/; nebo; RÁMIŠ, Vladan et al. Předběžné vyjádření Spolku pro ochranu osobních údajů k novele zákona č. 127/2005 Sb., navržené Ministerstvem zdravotnictví 30.11.2020. In: epravo.cz [online]. 17. 12. 2020 [cit. 22. 3. 2021]. Dostupné z: https:// www.epravo.cz/top/clanky/predbezne-vyjadreni-spolku-pro-ochranu-osobnich-udaju-knovele-zakona-c-1272005-sb-navrzene-ministerstvem-zdravotnictvi-30112020-112324.html 


\subsection{NEDŮSLEDNÉ ZPRACOVÁNÍ DPIA VZPOMÍNKOVÝCH MAP}

V této části bych se rád pozastavil nad stručností DPIA vzpomínkových map. Zpracovatel DPIA totiž zcela rezignoval na detailní popis způsobu získání dat od bank a mobilních operátorů a obsah těchto dat. Tyto informace nejsou ani součástí informací o zpracování osobních údajů vydaných Ministerstvem zdravotnictví ČR. Na druhou stranu jsou ale klíčové pro kvalifikované určení rizik pro práva a svobody subjektů údajů, jak požaduje čl. 35 odst. 7 písm. c) GDPR. Jejich útržky jsou dohledatelné až z jiných veřejně př́istupných zdrojů (mimořádné opatření, články autorů systému, informace od bank, ${ }^{103}$ aktuality České bankovní asociace ${ }^{104}$ apod.). Nelze se přitom domnívat, že by takovými informacemi správce nedisponoval. Jednak je jeho povinností, aby měl takové informace $\mathrm{k}$ dispozici, a jednak tyto informace jsou součástí smluv, které uzavřelo Ministerstvo vnitra ČR a společnost Keboole. ${ }^{105}$

Absence těchto informací při posuzování rizik ale může vést $\mathrm{k}$ opomenutí důležitých aspektů přenosu dat a jejich zabezpečení. $\mathrm{V}$ nejčernějších scénářích to pak může vést $\mathrm{k}$ únikům dat subjektů údajů a $\mathrm{v}$ důsledku ke snížení důvěry v českou chytrou karanténu. Za nepovedený příklad lze uvést neplánovaný přenos rodných čísel českých zájemců o očkování do USA. $^{106}$

Těmto problémům mohlo být předejito. Za kritickou chybu v tomto případě lze považovat nepřizvání si Úřadu pro ochranu osobních údajů ke konzultaci či neoslovení jiných zájmových skupin hned ze samého počátku projektu. Ačkoliv se v DPIA vzpomínkových map uvádí, že Úřad pro

\footnotetext{
${ }^{103}$ Informace o zpracování osobních údajů dle mimořádného opatření Ministerstva zdravotnictví ve věci předávání údajů o místě a době použití elektronického platebního prostředku [online]. Moneta Money Bank, [cit. 1. 9. 2020]. Dostupné z: https://www.moneta.cz/documents/ 20143/11740692/mmb-informace-o-zpracovani-osobnich-udaju-chytra-karantena.pdf

${ }^{104}$ Zapojení bank do „Chytré karantény“. In: Česká bankovní asociace [online]. 27. 4. 2020 [cit. 1. 9. 2020]. Dostupné z: https://cbaonline.cz/zapojeni-bank-do-chytre-karanteny.

${ }^{105}$ Smlouvy jsou dostupné z Registru smluv na adresách www.smlouvy.gov.cz/smlouva/ 12307632 a www.smlouvy.gov.cz/smlouva/12363956.

${ }^{106}$ Vyjádření Úřadu k rezervačnímu systému očkování proti COVID-19. In: Úřad pro ochranu osobních údajů [online]. 1. 2. 2021 [cit. 22. 2. 2021]. Dostupné z: https://www.uoou.cz/vyjadreni-uradu-k-nbsp-rezervacnimu-systemu-ockovani-proti-covid-19/d-47761
} 
ochranu osobních údajů a další osoby byly konzultovány, podle všeho tomu tak nebylo již od začátku. ${ }^{107}$

\subsection{PŘEDÁVÁNÍ OSOBNÍCH ÚDAJŮ MIMO EU}

Poslední z vytýkaných problémů vyvstal až v půlce roku 2020, kdy Soudní dvůr EU zrušil ${ }^{108}$ právní rámec pro předávání osobních údajů do USA na základě rozhodnutí o ekvivalentní ochraně (tzv. Privacy Shield). ${ }^{109} \mathrm{~V}$ obou zkoumaných částech české chytré karantény přitom vystupovaly společnosti se sídlem v USA v pozicích zpracovatelů, kterým přestalo být možné údaje bez dalšího předávat.

Další možností, jak v tomto případě právně zabezpečit předání osobních údajů do USA, jsou tzv. standartní smluvní doložky dle čl. 46 GDPR. Aby ovšem mohl správce předávat osobní údaje na tomto základě, musí ověřit, zda právo třetí země, do které je předáváno, má odpovídající ochranu osobních údajů a případně přijmout ještě další opatření. ${ }^{110}$ Není-li možné přijmout takové opatření, správce nesmí osobní údaje do dané země předat. Tak tomu bude dle Soudního dvora EU např. pokud jsou př́jemci údajů ve třetí zemi právem uloženy povinnosti, které jsou v rozporu se smluvními doložkami a „mohou tedy ohrozit smluvní záruku odpovídající úrovně ochrany před př́stupem orgánů veřejné moci uvedené třetí země $k$ těmto údajům. “111

Privacy Shield byl zrušen, protože USA neposkytují odpovídající úroveň ochrany, a to zejména protože využívají programy plošně sledující komu-

${ }^{107}$ ÚOOÚ k projektu „chytrá karanténa“. In: Úřad pro ochranu osobních údajů [online]. 11. 4. 2020 [cit. 1. 9. 2020]. Dostupné z: https://www.uoou.cz/uoou-k-nbsp-projektuchytra-karantena/d-41769; Vyjádření Spolku pro ochranu osobních údajů $k$ projektưm Chytrá karanténa a eRouška [online]. Spolek pro ochranu osobních údajů, 2020 [cit. 01.09.2020]. Dostupné z: https://www.ochranaudaju.cz/wp-content/uploads/2020/05/Chytra_karantena_stanovisko_final.pdf

${ }^{108}$ Rozsudek Soudního dvora EU ze dne 16. 7. 2020, Schrems II., C-311/18, EU:C:2020:559, odst. 201.

${ }^{109}$ Prováděcí rozhodnutí Komise (EU) 2016/1250 ze dne 12. července 2016 podle směrnice Evropského parlamentu a Rady 95/46/ES o odpovídající úrovni ochrany poskytované štítem EU-USA na ochranu soukromí.

${ }^{110}$ Rozsudek Soudního dvora EU Schrems II., odst. 133 a 134.

${ }^{111}$ Ibid., odst. 135. 
nikaci včetně jejího obsahu. ${ }^{112}$ Soudní dvůr EU explicitně konstatoval, že právní úprava omezující soukromí v USA není „upravena takovým způsobem, aby odpovídala požadavkům, které jsou $v$ zásadě rovnocenné požadavkům vyžadovaným $v$ unijním právu“. ${ }^{113}$ Nabízí se tak zcela očividná otázka, zda může správce dojít vlastním hodnocení při uzavírání smluvních doložek k opačnému závěru ${ }^{114}$ a osobní údaje tak na základě smluvních doložek opět předávat.

Domnívám se, že tomu tak v současné situaci není. ${ }^{115}$ At již bude předávání osobních údajů zastřešeno smluvně jakkoliv, takový způsob nemá přednost před veřejnoprávními zákonnými ustanoveními tamního právního řádu. ${ }^{116}$ Někteří autoři zmínili namísto přesunu dat do EU možnost zašifrování přeneseného obsahu. ${ }^{117}$ Jak ale jedním dechem dodávali, jedná se o technicky, časově a finančně náročné řešení. Jako takové potom není $\mathrm{v}$ tomto případě ihned připravené zajistit práva občanů EU.

Stejně jako v předchozích kapitolách, i zde eRouška díky své nové verzi unikla negativnímu hodnocení. U vzpomínkových map je současná situace nejistá. Jejich DPIA uvádí společnost Amazon jako subzpracovatele a USA

\footnotetext{
${ }^{112}$ Ibid., odst. 178-184.

${ }^{113}$ Ibid., odst. 185.

${ }^{114}$ NEŠPŮREK, Robert a Vojtěch BARTOŠ. EU-US Privacy Shield zrušen. Předávání osobních údajů do USA podle standardních smluvních doložek mohou úrady kdykoliv zakázat. [online]. 2020 [cit. 20. 8. 2020]. Dostupné z: https://www.havelpartners.blog/blog/eu-us-privacyshield-zrusen-predavani-osobnich-udaju-do-usa-podle-standardnich-smluvnich-dolozek-mohou-urady-kdykoliv-zakazat/147

${ }^{115}$ Pro stejný názor a shrnutí přístupů dohledových úřadů srov. BARNEY, Gwenn. Does Schrems II Doom Use of SCCs for EU-US Data Transfers? No Answers and Clouds are Gathering. In: JD Supra [online]. 4. 11. 2020 [cit. 22. 2. 2021]. Dostupné z: https://www.jdsupra.com/legalnews/does-schrems-ii-doom-use-of-sccs-for-eu-15488/; nebo MAĎAROVÁ, Helga. Schrems II: zásadná zmena v podmienkach prenosu osobných údajov mimo EÚ. In: epravo.sk [online]. 1. 10. 2020 [cit. 7. 3. 2021]. Dostupné z: https://www.epravo.sk/top/ clanky/schrems-ii-zasadna-zmena-v-podmienkach-prenosu-osobnych-udajov-mimo-eu4905.html

${ }^{116} \mathrm{Na}$ systém zastřešený prostřednictvím standartních smluvních doložek přešel např. Amazon. Viz SCHMIDT, Stephen. Customer update: AWS and the EU-US Privacy Shield [online]. 2020 [cit. 1. 9. 2020]. Dostupné z: https://aws.amazon.com/blogs/security/customer-update-aws-and-the-eu-us-privacy-shield/

${ }^{117}$ Za všechny OLEJNIK, Lukasz. Technology impact of Privacy Shield invalidation - is it the EU data localization? [online]. 2020 [cit. 1. 9. 2020]. Dostupné z: http://blog.lukaszolejnik.com/technology-impact-of-privacy-shield-invalidation-is-it-the-eu-data-localization/
} 
jako místo zpracování dat, ${ }^{118} \mathrm{z}$ informační povinnosti nelze zjistit více. ${ }^{119}$ Zůstává také otázkou, jaké konkrétní osobní údaje jsou mimo EU zpracovány. Potenciálně se ovšem může jednat o vážný zásah, protože u vzpomínkových map jsou zpracovány údaje chráněné telekomunikačním tajemstvím spolu s rodným číslem a dalšími identifikačními údaji.

\section{5 ČESKÉ SHRNUTÍ}

$\mathrm{V}$ případě české chytré karantény byl problém především $\mathrm{v}$ nedostatečném právním základu (třetí krok testu ESLP), který byl vytvořen nedostatečným zájmem zákonodárné a výkonné moci. Dostatečně kvalitní právní rámec přitom mohl být nastaven poměrně rychle. ${ }^{120} \mathrm{~V}$ případě eRoušky byl nakonec odpovídající právní rámec přijat na začátku roku 2021, u vzpomínkových map je situace o poznání horší. Jejich právní základ je totiž stále v legislativním procesu, a navíc nelze navrhovanou normu považovat za kvalitní.

Kromě toho vzpomínkové mapy trpí i dalšími problémy jako je nedostatečně zhodnocený způsob zpracování osobních údajů (především způsob získávání údajů) a neexistence novějšího DPIA či alespoň informační povinnosti správce reflektující právní (zrušení Privacy Shieldu) i faktický (upuštění od využívání dat od bank) vývoj.

Celkově lze ale hodnotit českou chytrou karanténu jako proporcionální zásah do práva na soukromí. Tvưrci aplikací v rámci překotného vývoje v zásadě zvolili rozumná řešení, které dbali zásad ochrany osobních údajů, a to i v prvních verzích.

Jedním dechem je třeba dodat, že technologie, jako je chytrá karanténa, plní v současné pandemii roli pouze jednoho kolečka ve velkém soukolí. Nejde o samospasné řešení na pandemii, které nás bez dalšího zachrání.

${ }^{118}$ DPIA vzpomínkových map, s. 13 a 14.

${ }^{119}$ Chytrá karanténa - Aktuální informace o COVID-19.

${ }^{120}$ Např́klad zákon č. 94/2021 Sb., o mimořádných opatřeních při epidemii COVID-19, který obsahuje právní základ pro aplikaci eRouška, byl Poslanecké sněmovně Parlamentu ČR předložen 15. 2. 2021 a o pouhých 11 dní později, dne 26. 2. 2021 byl vyhlášen ve Sbírce zákonů ČR. Srov. Sněmovní tisk 1158. In: Poslanecká sněmovna Parlamentu ČR [online] [cit. 23.03.2021]. Dostupné z: https://www.psp.cz/sqw/historie.sqw?o $=8 \& \mathrm{t}=1158$ 
Nejlépe to lze demonstrovat na českých vzpomínkových mapách, které v současné době přestávají plnit svůj účel, nebot každý nahlásí v průměru pouze jeden rizikový kontakt. ${ }^{121}$ Větší efektivitu zde nepřinese ani zmiňovaný návrh § 89a ElKomČR, který by umožnil polohová data předávat hygienickým stanicím bez souhlasu uživatele. Ze samostatných dat o pohybu není možné bez asistence nakaženého identifikovat další, potenciálně nakažené, osoby. Stejně na tom pak je i eRouška, kterou v současné době používá přibližně čtvrtina lidí potřebných $\mathrm{k}$ dostatečné funkčnosti aplikace. $^{122}$

\section{ANALÝZA SLOVENSKÉHO ŘEŠENÍ}

\subsection{PŘEDÁVÁNÍ ÚDAJŮ ÚVZ PŘEZKOUMANÉ ÚSTAVNÍM SOUDEM SR} Jak již bylo $v$ popisu slovenského řešení zmíněno, Ústavní soud SR odmítnul první verzi legislativy, která umožňovala ÚVZ žádat mobilní operátory o údaje občanů. Tato kapitola se tomuto rozhodnutí věnuje, shrnuje jeho závěry a následně je aplikuje na verzi legislativy, kterou přijal slovenský zákonodárce v reakci na toto rozhodnutí. ${ }^{123}$

Zavedený systém povinoval mobilní operátory k uchovávání údajů a k jejich zpřístupnění veřejné moci na žádost ÚVZ. ${ }^{124}$ Ústavní soud SR při přezkoumávání využil v souladu s judikaturou Soudního dvora EU přísných

\footnotetext{
${ }^{121}$ Lidé porušují karanténu. V lednu ji nedodržela třetina z pěti set kontrolovaných. In: Aktuálně.cz [online]. 4. 2. 2021 [cit. 12. 3. 2021]. Dostupné z: https://zpravy.aktualne.cz/ domaci/karantenu-porusila-v-lednu-tretina-kontrolovanych/r c369cbde66f711eb842f0cc47ab5f122/

${ }^{122}$ Pro její maximální účinnost si jí musí nainstalovat 6 mil. lidí, zatímco na konci roku 2020 mělo eRoušku nainstalováno „pouze“ 1,5 mil. lidí. Srov. Aplikaci eRouška si zatím aktivoval milion lidí. Nové uživatele ,nalákala' SMS výzva [online]. Lidovky.cz. 14. 10. 2020 [cit. 12. 3. 2021]. https://www.lidovky.cz/domov/aplikaci-erouska-si-zatim-aktivovalo861-tisic-lidi-nove-uzivatele-nalakala-sms-vyzva.A201014 _142758_ln_domov_sei; a Fišer, M. Aplikaci eRouška už používá 1,5 milionu lidí [online]. Novinky.cz. 31. 12. 2020 [cit. 12. 3. 2021]. https://www.novinky.cz/internet-a-pc/software/clanek/aplikaci-erouska-uz-pouziva-15-milionu-lidi-40346571

${ }^{123}$ Na ono rozhodnutí Ústavního soudu se odkazuje při svém vetu i prezidentka SR ve svém rozhodnutí ze dne 3. 8. 2020, č. 4823-2020-KPSR, s. 3.

${ }^{124}$ Usnesení Ústavního soudu SR č. j. PL. ÚS 13/2020-103, odst. 63, 64 a 67.
} 
kritérií. ${ }^{125}$ Došel při tom $\mathrm{k}$ závěru, že přezkoumávaná právní úprava absentuje na záruky, které jsou požadované jak jeho rozhodovací praxí, tak judikaturou Soudního dvora EU. Jedná se o:

- $\quad$ subsidiaritu použivání získaných údajů - Ústavní soud SR akcentoval princip, že údaje je nutné získávat $\mathrm{z}$ nejméně citlivých zdrojů a pouze $\mathrm{v}$ nevyhnutelném rozsahu (např. pouze pro omezené časové okno na inkubační dobu nebo limitováno způsobem šíření viru). V tomto ohledu také připomněl, že by zpracování mělo být prováděno na základě souhlasu; ${ }^{126}$

- jasné vymezení účelu použití těchto údajů - zákonné ustanovení podle Ústavního soudu SR nestanovilo účel použití osobních údajů dostatečně jasně a fungovalo vlastně jako generální klauzule; ${ }^{127}$

- $\quad$ kvalitní dohled ze strany soudu nebo nezávislého orgánu - v rámci tohoto bodu Ústavní soud SR vyzvedl skutečnost, že není možné udělit sankce $\mathrm{v}$ př́ípadě porušení předmětných ustanovení ze strany ÚVZ. Úpravě chybělo i zajištění transparentnosti pro umožnění veřejné kontroly; ${ }^{128}$

- zabezpečení vysoké úrovně ochrany a bezpečnosti - čím citlivější údaje, tím lepší (technickou) ochranu je jim třeba poskytnout; ${ }^{129}$

- c časově podmíněné zničení údajů - pro minimalizaci rizika zneužití údajů je nutné, po odpadnutí důvodu zpracování v daném množství a kvalitě, je znehodnotit či zničit; ${ }^{130}$

- Vyrozumění dotčených osob - pokud je možné dotčené osoby vyrozumět o poskytnutí jejich údajů (tedy nebrání-li tomu nějaký zákonný důvod nebo obdobný zájem), musí tak být učiněno. To je

\footnotetext{
${ }^{125}$ Ibid., odst. 81.

${ }^{126}$ Ibid., odst. 89 a 90. Vyžadování souhlasu pro poskytnutí údajů sice vláda SR uvádí ve vyjádření adresovaném Ústavním soudu SR (srov. Ibid., odst. 57). Absence takové podmínky v zákonném znění je však deficitem, který se nedá překonat výkladem.

${ }^{127}$ Ibid., odst. 85 a 91.

${ }^{128}$ Ibid., odst. 92.

${ }^{129}$ Ibid., odst. 93.

${ }^{130}$ Ibid., odst. 94.
} 
vyjádřením požadavku na přístup $\mathrm{k}$ soudu a k efektivní soudní kontrole. $^{131}$

Nejznatelnější změnou v novelizaci provedené na základě pozastavení účinnosti bylo zakotvení povinnosti získat souhlas s poskytnutím údajů. Zákon vyžadoval souhlas pouze k poskytnutí údajů, jejich zpracování se pak zřejmě provádělo na základě titulu plnění právní povinnosti. Takto nastavený systém nelze považovat apriori za problematický - subjektu údajů byla stále na začátku dána možnost volby, zda osobní údaje pro tento účel poskytne.

Ačkoliv byl výmaz osobních údajů povinen provést správce, nejsou-li již potřeba pro příslušné účely, v rámci zvýšení transparentnosti a posílení právní jistoty je opětovná deklarace tohoto pravidla vítaná. $S$ transparentností souvisí i povinnost ÚVZ předložit zprávu Národní radě SR o zákonnosti zpracování.

Zůstává ovšem otázkou, jestli byl vyřešen i problém s nedostatečně určenými účely zpracování. Novelizace totiž stanovila možnost zpracovat údaje „výlučne $v$ rozsahu potrebnom na identifikáciu pohybu dotknutého užívatel'a $v$ záujme ochrany života a zdravia.“132 Podle mého názoru nedošlo, oproti původnímu znění, ke znatelnému zúžení účelu dle požadavku Ústavního soudu SR. V jeho rozhodnutí se jako př́klad dostatečně konkrétních účelů uvádělo informování obyvatelstva, vynucování karantény nebo případné vedení přestupkových a trestních řízení. ${ }^{133}$ Zákonodárce ovšem ponechal účel definovaný obecně jenom jako „ochranu života a zdraví“. Jednalo se tak o stejnou generální klauzuli, jakou původně Ústavní soud SR kritizoval.

Při hodnocení je nutné dodat, že ze zmíněné zprávy, kterou ÚVZ předložil Národní radě SR, vyplývá, že za celou dobu využitelnosti tohoto právního rámce (do 31. 12. 2020) ${ }^{134}$ ÚVZ ani jednou nepožádal mobilní operátory

\footnotetext{
${ }^{131}$ Ibid., odst. 95.

${ }^{132}$ Ustanovení § 63 odst. 18 odst. c) ElKomSR.

${ }^{133}$ Usnesení Ústavního soudu SR č. j. PL. ÚS 13/2020-103, odst. 85 a 91.

${ }^{134}$ To je totiž podle $\S 63$ odst. 20 ElKomSR nejzazší den, kdy může ÚVZ zpracovávat a uchovávat údaje takto získané.
} 
o zpř́stupnění údajů. ${ }^{135}$ Nebyly tedy zpracovány jakékoliv osobní údaje. Optikou Úmluvy a ESLP, jak byly prezentovány na začátku, nedošlo k zásahu do práv občanů. Nicméně tento závěr neznamená automatickou konformitu úpravy s Ústavou SR či slovenskými mezinárodními závazky. Identifikované problémy právní úpravy by napřriště měly být slovenským zákonodárcem reflektovány.

\subsection{PŘEDÁVÁNÍ TELEFONNÍHO ČÍSLA ÚVZ}

Ačkoliv si zřejmě zákonodárce vzal nějaká ponaučení pro zásahy do soukromí a ochranu osobních údajů pro schvalování další úpravy (přijetí $\S 42$ odst. 5 a § 63 odst. 21 ElKomSR), nebyl minimálně ve třech ohledech zcela důsledný. Pro připomenutí, jedná se o zplnomocnění ÚVZ k vyžádání si telefonních čísel osob, kterým byla zaslána varovná textová zpráva. V současné době jsou příslušná ustanovení stále využitelná.

Zaprvé, tato nová úprava trpí stejně nedostatečně určeným účelem, jako úprava původní. Ustanovení jako účel uvádí ochranu osob před hrozícím nebezpečím anebo přijímání opatření při ohrožení života a zdraví. ${ }^{136}$ Vyzněním se tak jedná taktéž o generální klauzuli, která ÚVZ umožňuje zpracování osobních údajů pro množství účelů, a nikoliv pouze pro onu kontrolu osob přicházejících $\mathrm{z}$ „červených zemí“, jak deklaruje důvodová zpráva.

Zadruhé není vůbec jasné, proč je doba pro zpracování zrovna 60 dní. ${ }^{137}$ Osoby překračující hranice se musí hlásit bezprostř̌edně po vstupu na území, přičemž v opačném př́ípadě jim hrozí správní sankce. ${ }^{138} \mathrm{Z}$ jakého důvodu zákonodárce umožňuje údaje zpracovávat šedesát dní od poskytnutí se ze znění ustanovení nebo důvodové zprávy nedovíme.

\footnotetext{
${ }^{135}$ Správa o zákonnosti spracúvania údajov v súlade s $§ 63$ ods. 20 ElKomSR, s. 5. Po omezený čas k dispozici z: https://cutt.ly/6kFsfgD. Tento dokument byl získán na základě žádosti autora podle SlInf. Odpověd’ povinného subjektu nebyla publikována, po omezený čas je k dispozici z: https://cutt.ly/lkFsDIq.

${ }^{136}$ Ustanovení § 63 odst. 21 ElKomSR.

137 Ibid.

${ }^{138}$ Opatrenie ÚVZ pri ohrození verejného zdravia ze dne 17. 9. 2020, sp. zn. OLP/7310/2020.
} 
Zatřetí, zákon zcela rezignuje na informování osob, jejichž číslo bylo ÚVZ poskytnuto. Dle mého názoru zde přitom nelze identifikovat důvod, pro který by dotčené osoby nemohly být o tomto předání údajů notifikovány (alespoň ex post). Jde tak reálně o méně lidskoprávně přívětivou úpravu, než je úprava odposlechů ve slovenských trestněprávních předpisech. ${ }^{139}$

Stejně jako $v$ případě oprávnění podle $\S 63$ odst. 18 až 20 ElKomSR, ani zde ÚVZ nepožádal o ani jednou o zpř́istupnění údajů. ${ }^{140}$ Nebyly tedy zpracovány jakékoliv osobní údaje a aplikují se výše uvedené závěry.

Je nutné poznamenat, že skrze tuto úpravu má ÚVZ př́istup pouze $\mathrm{k}$ telefonnímu číslu. Vyhodnocení, která telefonní čísla budou předána, je na mobilních operátorech. Nebude se tak jednat o zásah stejné intenzity jako v předcházející kapitole. Na druhou stranu, i u takové úpravy je nutné trvat alespoň na předchozím patřičném odůvodnění. To ovšem $v$ tomto př́ípadě zpracováno nebylo, nebot̉ důvodová zpráva k zákonu je velmi stručná a nezaobírá se důležitými aspekty. Pro srovnání: tato podkapitola je o jen o deset slov kratší než obecná část důvodové zprávy v kombinaci s odůvodněním $\S 61$ odst. 21 ElKomSR.

\subsection{KONTROLA PROSTŘEDNICTVÍM EKARANTÉNY}

Aplikace eKaranténa je již na první pohled invazivnější do soukromí než česká eRouška. To ovšem, s ohledem na její způsob využití (hlídání dodržování nařízené karantény oproti trasování kontaktů) není př̌kvapivé.

Podíváme-li se na toto řešení optikou pětistupňového testu popsaného na začátku, nemám pochyb o tom, že prvními čtyřmi kroky projde řešení bez problému. $\mathrm{V}$ tomto př́padě je čl. 8 Úmluvy aplikovatelný (krok 1), zásah zde existuje v podobě povinnosti nechat se sledovat (krok 2), celé řešení má zákonný právní rámec (§ 60a a násl. OchrZdrSR) (krok 3) a sleduje legitimní cíl ochrany veřejného zdraví uvedený v čl. 8 odst. 2 Úmluvy (krok 4).

\footnotetext{
${ }^{139}$ Ustanovení § 116 odst. 4 zákona č. 301/2005 Z. z., trestný poriadok.

${ }^{140}$ Správa o zákonnosti spracúvania údajov v súlade $s \S 63$ ods. 21 ElKomSR, s. 3. Po omezený čas dostupné z: https://cutt.ly/7b3Q9WG. Tento dokument byl získán na základě žádosti autora podle SlInf. Odpověd’ povinného subjektu nebyla publikována, po omezený čas je k dispozici z: https://cutt.ly/Yb3Q7Ez.
} 
Nicméně jsem toho názoru, že systém eKarantény již neprojde pátým krokem, testem nezbytnosti (proporcionality).

Křivka počtu nakažených měla v zemích EU v zásadě stejný vývoj. Po prvotním zvýšení počtu nakažených se trend křivky otočil a počet případů začal klesat. ${ }^{141}$ Slovensko přitom bylo jednou z mála zemí, která zvolila tento způsob vynucování karantény. ${ }^{142}$ Nelze tak konstatovat, že by tento způsob měl svoji přidanou hodnotu (zejm. rychlejší zvládnutí pandemie), kterým by mohl tento zásah do soukromí odůvodněn. Tento př́istup tak je nutné zařadit na list bad practice.

Dále je možné zabývat se námitkou diskriminace. Z dostupných zdrojů totiž vyplývá, že povinnost absolvovat tento způsob karantény dopadal pouze na osoby vracející se na Slovensko ze zahraničí. Osoby pobývající na území Slovenska, které se tam i nakazily, tuto povinnost neměly a absolvovaly izolaci v domácím prostředí bez dohledu eKarantény. ${ }^{143}$ Takto rozdílné zacházení se dvěma srovnatelnými skupinami obyvatel (osoby nakažené koronavirem či s podezřením na nákazu) není vůbec odůvodněno. Na základě čeho došla slovenská exekutiva k závěru, že repatrianty je nutné hlídat skrze eKaranténu ale osoby trvale pobývající a nakažené na území Slovenska nikoliv? Existuje u nich snad větší předpoklad porušování izolace? To se již nedovíme.

V neposlední řadě bych rád zmínil, dle mého názoru, obecně chybné nastavení eKarantény. Jejím základním předpokladem totiž je, že všichni lidé nebudou izolaci dodržovat, a proto je nutné je nepřetržitě hlídat skrze GPS a fotografie. Domnívám se, že taková plošná presumpce je nepřípustná, jelikož nutí strpět větší zásah do práv všechny osoby, a nikoliv pouze ty, které izolaci porušily (jako je tomu např. u pokut) či se lze důvodně domnívat,

${ }^{141}$ COVID-19 country overviews. In: Evropské středisko pro prevenci a kontrolu nemocí [online]

[cit. 4. 10. 2020]. Dostupné

z: https://covid19-country-overviews.ecdc.europa.eu/\#3_eueea_and_the_uk

${ }^{142}$ Projects using personal data to combat SARS-CoV-2.

${ }^{143}$ Jak aplikovatelné Opatrenie ÚVZ pri ohrození verejného zdravia sp. zn. OLP/4311/2020, tak i tiskové zprávy (např. COVID-19: Inteligentná domáca karanténa by sa mala spustit od piatku. In: Ministerstvo zdravotníctva SR [online]. 19. 5. 2020 [cit. 8. 3. 2021]. Dostupné z: https://www.health.gov.sk/Clanok?covid-19-19-05-2020-karantena-smart) se zmiňují výhradně o osobách vracejících se ze zahraničí v souvislosti s aplikací eKarantény. 
že ji poruší. ${ }^{144}$ Navíc byla tato povinnost vynucována u osob pouze z důvo$\mathrm{du}$, že překročily hranice (v kontrastu např. s osobami, které spáchaly trestný čin, pročež je jejich pohyb monitorován $\mathrm{v}$ rámci výkonu trestu). Analogicky lze tento způsob sledování připodobnit $\mathrm{k}$ situaci, kdy stát provádí plošné odposlechy všech telefonů značky Apple, a nikoliv osob s důvodným podezřením na páchání trestné činnosti.

Potřeba získat souhlas dotčené osoby se $\mathrm{v}$ tomto príípadě nedá považovat za zmírnění zásahu. Druhá možnost karantény repatriantů probíhala v budově $\mathrm{k}$ tomu určené státem. ${ }^{145}$ Podmínky $\mathrm{v}$ těchto zařízeních byly mnohdy hraniční ${ }^{146}$ a zabývala se jimi i slovenská ombudsmanka. ${ }^{147}$ Ta se nakonec ohledně karantény obrátila na jaře 2021 i na Ústavní soud SR s žádostí o přezkum postupu vlády $\mathrm{SR}^{148}$ To tak může vést $\mathrm{i} \mathrm{k}$ úvahám o (ne)dobrovolnosti uděleného souhlasu, nebot pokud jej osoba neudělila a nenastoupila do domácí karantény hlídané eKaranténou, byla nucena izolaci strávit ve státním zařízení, kde podmínky nemusí splňovat základní požadavky.

${ }^{144}$ Zde lze odkázat i na kritiku plošného sběru provozních a lokalizačních údajů a jejich předávání bezpečnostním složkám. $\mathrm{V}$ těchto případech Soudní dvưr EU shledal, že takové opatř̌ení není v demokratické společnosti možné považovat za odůvodněné, nebot stát schraňuje i údaje osob, u kterých neexistuje důvod domnívat se, že jejich chování souvisí se zajištěním národní bezpečnosti. Srov. rozsudek Soudního dvora EU ze dne 6. října 2020, Privacy International, C-623/17, EU:C:2020:790, odst. 80 a 81 a judikaturu tam citovanou.

${ }^{145}$ Tento typ karantény je vlastně výchozí možností. Domácí karanténa za dohledu aplikace eKaranténa je až alternativní možností, která dostupná na žádost.

${ }^{146}$ NEČÁSKOVÁ, Pavlína. Společné pokoje, odtažitý personál, destinace předem neznámá. Slováci sdílejí zážitky ze státní karantény. In: iROZHLAS [online]. 6. 5. 2020 [cit. 8. 3. 2021]. Dostupné z: https://www.irozhlas.cz/zpravy-svet/slovensko-statni-karantena-koronavirus-cestovani-hranice_2005061304_kro

147 Ombudsmanka odporúča zmenit systém povinnej štátnej karantény - tisková zpráva [online]. Kancelária verejného ochrancu práv, 2020 [cit. 8. 3. 2021]. Dostupné z: https://www.vop.gov.sk/files/2020_23_TS_VOP_odporuca_zmenit_system_povinnej_statne j_karanteny.pdf

${ }^{148}$ Ombudsmanka sa obrátila na Ústavný súd, žiada posúdenie zásahov do práv počas pandémie. In: RTVS: Správy [online]. 10. 2. 2021 [cit. 8. 3. 2021]. Dostupné z: https:// spravy.rtvs.sk/2021/02/ombudsmanka-sa-obratila-na-ustavny-sud-ziada-posudenie-zasahov-do-prav-pocas-pandemie/; Ústavní soud SR pak celý návrh přijal k dalšímu řízení, viz Ústavný súd prijal moje podanie na d’alšie konanie. In: Verejný ochranca práv [online]. 30. 4. 2021 [cit. 20. 5. 2021]. Dostupné z: https://www.vop.gov.sk/stavn-s-d-prijal-mojepodanie-na-al-ie-konanie 
Prezentovaným způsobem zpracování osobních údajů tak dle mého názoru dochází nejen k porušení principu minimalizace osobních údajů, ${ }^{149}$ ale jedná se o zásah do práv zaručených lidskoprávními katalogy vyčtenými v úvodu. Právní předpisy by totiž měly mj. zajistit, aby zpracovávaná data byla relevantní a přiměřená účelu, pro který jsou zpracovávána, ${ }^{150}$ tak, aby byl zásah co nejmenšího rozsahu. To se v tomto př́ípadě nestalo.

\subsection{AUTOMATIZOVANÉ INDIVIDUÁLNÍ ROZHODOVÁNÍ V EKARANTÉNĚ?}

Při hodnocení, zda osoba porušila karanténu, docházelo $\mathrm{k}$ jejímu profilování. Aplikace sama vyhodnocovala, zda se osoba vzdálila od místa nahlášené karantény, případně o kolik. Došlo-li ke vzdálení se, odeslala orgánům veřejné moci hlášení. Ze zákona ovšem musí být porovnání fotografií (s fotografií vloženou do aplikace při registraci) a polohy prováděno přímo na zařízení, kde také musí být tyto údaje uloženy. Jejich uložení na externích serverech nebo zpř́stupnění jiným osobám je explicitně zakázáno. ${ }^{151}$

$\mathrm{Z}$ důvodové zprávy poté vyplývá, že v př́padě neshody fotografií bylo na server odesláno hlášení, které obsahovalo pouze informaci o neshodě fotografií. Obdobně to platí pro porovnávání lokalizačních údajů. V tomto se rozchází důvodová zpráva s publikovanou informační povinností správce, kde se u kapitoly o profilování uvádí pouze informace $\mathrm{k}$ hodnocení polohy. ${ }^{152}$

Zřejmě tomu bude tak $\mathrm{z}$ důvodu, že pro projednání přestupků byla správnímu orgánu zpřístupněna pouze informace o porušení karantény a závažnosti tohoto porušení, nikoliv přesné polohové údaje. ${ }^{153} \mathrm{~S}$ výsledkem porovnání fotografií se tak z nějakého důvodu pro přestupkové řízení podle dikce zákona nebo informační povinnosti správce nepočítalo.

${ }^{149}$ Čl. 5 odst. 1 písm. c) GDPR.

${ }^{150}$ Garder proti Francii, rozsudek ESLP, 17. 12. 2009, č. stí́žnosti 16428/05, odst. 62.

${ }^{151}$ Ustanovení § 60d odst. 5 OchrZdrSR.

${ }^{152}$ Podmienky ochrany súkromia - eKaranténa. In: Korona.gov.sk [online] [cit. 04. 10. 2020]. Dostupné z: https://korona.gov.sk/podmienky-ochrany-sukromia-ekarantena/

${ }^{153}$ Ustanovení § 60c odst. 2 OchrZdrSR. 
Důležitým ustanovením v tomto př́padě je i § 54 odst. 5 OchrZdrSR, který opravňuje vykonávat státní zdravotní dozor dodržování domácí karantény pouze prostřednictvím aplikace eKaranténa.

Prvním zjevným nedostatkem zde bylo vynechání jakýchkoliv informací o porovnání fotografií a odesílání případného hlášení upozorňující na neshodu fotografií. $\mathrm{V}$ tomto případě docházelo taktéž k profilování.

Vyvstává zde ale mnohem důležitější otázka - a to, jak doopravdy fungoval proces ukládání pokut za nedodržení karantény? Informační povinnost správce totiž uváděla, že na základě hlášení se přestupkové řízení pouze zahajuje a rozhodnutí, kterým se končí pak mělo vždy „lidskou povahu“. ${ }^{154}$ Jinými slovy, nedocházelo k automatizovanému rozhodování a neuplatní se čl. 22 GDPR (obsahující např. právo na ověření rozhodnutí neautomatizovaným způsobem).

Při hodnocení, zda rozhodování spadá pod čl. 22 GDPR, je jedna z důležitých skutečností role člověka $\mathrm{v}$ rozhodovacím procesu. Pokud je jeho účast vyfabrikovaná nebo jeho činností je pouze na základě předložených údajů vydat v mezích (např. interních) instrukcí rozhodnutí, správce se přidaným povinnostem nevyhne. ${ }^{155}$ Jako př́klad takového lidského automatizovaného rozhodování lze uvést uložení pokuty za překročení rychlosti pouze na základě důkazů z radaru. ${ }^{156}$

Pokud tedy ukládání pokut za porušení karantény bylo prováděno pouze na základě onoho hlášení (přičemž není jisté, jak jinak by měl správní orgán obstarat další důkazy, když není ze zákona oprávněn domácí karanténu kontrolovat jinak), může se jednat o automatizované rozhodování. V takovém případě pak zajisté vyvstává i otázka, jakým způsobem by mohlo být rozhodnutí aplikace o zaslání hlášení přezkoumáváno, když podkladové údaje nesmí opustit mobilní zařízení osoby a správní orgán tak k nim nemá prístup.

\footnotetext{
${ }^{154}$ Podmienky ochrany súkromia - eKaranténa.

${ }^{155}$ Pokyny WP29 k automatizovanému individuálnímu rozhodování a profilování pro účely nařízení 2016/679, s. 21.

${ }^{156}$ Pokyny WP29 k automatizovanému individuálnímu rozhodování a profilování pro účely nařízení 2016/679, s. 8.
} 


\subsection{SLOVENSKÉ SHRNUTÍ}

Ani jednu z částí slovenské chytré karantény nelze hodnotit pozitivně. Nastavení aplikace eKaranténa představovalo neproporcionální zásah do práva na soukromí a zákonný rámec pro předávání údajů od mobilních operátorů je nedostatečný, a to i přes rychlý zásah Ústavního soudu SR. Zákonodárce jím předložené požadavky $\mathrm{v}$ dalších legislativních procesech $\mathrm{z}$ části prostě ignoroval. Zamyšlení by mělo být při nastavování chytrých karantén věnováno také využitelnosti přijatých instrumentů, nebot ÚVZ nové pravomoci vyžádat si informace od mobilních operátorů nakonec (at̉ už z jakéhokoliv důvodu) nevyužil ani jednou.

Vyzdvihnut by pak měl být přístup ÚVZ $\mathrm{k}$ DPIA, a to jak $\mathrm{v}$ případě osobních údajů získaných od operátorů, tak v případě aplikace eKaranténa. V prvním případě totiž DPIA zpracováno vůbec nebylo, v druhém případě jej pak ÚVZ nemá fyzicky k dispozici (má jej pouze advokátní kancelář, která jej vypracovala) a odmítá jej poskytnout. Absence těchto podkladů (či jejich utajování) pak ztěžuje veřejnou diskusi o proporcionálnosti použitých řešení.

Právě slovenský přístup dle mého názoru příkladně ukazuje, že při nastavování chytrých karantén je klíčová právě proporcionalita řešení (pátý stupeň testu ESLP). Jak totiž demonstrovala aplikace eKaranténa, ostatní čtyři stupně testu je možné v současné pandemii poměrně lehce splnit. Proporcionalita řešení se nicméně $\mathrm{v}$ čase mění, a to $\mathrm{v}$ závislosti na aktuální situaci. Lze si tak představit poměry, ve kterých by takovéto plošné sledování osob v karanténě mohlo být považováno za proporcionální. Odůvodnění zavedení tohoto opatření ale může být dle mého názoru založeno jen a pouze na (ne)chování lidí. To stejné platí pro jakékoliv zasahování do soukromí skrze chytré karantény a jiná technická řešení.

Na rozdíl od některých jiných základních práv, na které pandemie taktéž dopadá nebo může dopadnout (shromažd’ovací právo, vlastnické právo či zákaz nucené práce), nelze zásah do práva na soukromí obhájit pouhými daty o počtu nakažených, rychlostí šíření viru anebo nedostatkem volných lůžek v nemocnicích. Zatímco omezení shromažd’ovacího práva má logicky bez dalšího potenciál snížit rychlost šíření onemocnění v populaci, jelikož 
se lidé nesetkají, nepřetržité sledování izolovaných osob samo o sobě nic takového nedokáže.

V jakých poměrech by tedy mohlo být považováno plošné sledování osob v izolaci za proporcionální? Domnívám se, že by k tomu mohlo dojít pouze $\mathrm{v}$ případech značného porušování nařízených izolací - tedy argumentem založeným na (ne)chování lidí. Jen tehdy je totiž možné učinit výše nastíněnou dedukci (nepřetržité sledování snižuje počet osob porušujících nařízenou karanténu, což má potenciál snížit rychlost šíření onemocnění). Získání relevantních dat přitom nepředstavuje nějaký nepředstavitelný proces. $^{157}$

Tímto způsobem pak bude do práva na soukromí zasahováno pouze ve skutečně odůvodněných případech. Zi̊stane tak ochráněno před ostatními vlivy, jako je rychlost šíření onemocnění, jeho smrtnost, nedůvěra občanů vládě či odborná správnost nastavených opatření, které nemají se soukromím žádné přímé spojení.

Konkrétně se pak toto dá demonstrovat právě na aplikaci eKaranténa. Byl-li by tento zpo̊sob vynucení přijat, protože repatrianti hromadně porušují domácí karanténu a šíří nákazu, zákonitě by musela být křivka nakažených jiná než v ostatních evropských zemích, které zvolily odlišný přístup. Zpětně lze ale z vývoje počtu nakažených konstatovat, že k ničemu takovému nedošlo. Zákonodárce tedy neměl ani nemohl mít relevantní důvod (či podklady) zasahovat to práva na soukromí tímto způsobem.

\section{ZÁVĚR}

Příspěvek se blíže zabýval oficiálními chytrými karanténami v Česku a na Slovensku z pohledu práva na soukromí. Zkoumání byly podrobeny pře-

\footnotetext{
${ }^{157}$ Např. za leden 2021 bylo nařízeno 245.000 karantén (srov. Lidé porušují karanténu. V lednu ji nedodržela třetina z pěti set kontrolovaných.). Pokud bychom využili všech 26.000 policistů hlídajících hranice okresů, aby ve dvojicích karantény postupně kontrolovaly, vychází na každou dvojici zkontrolovat 18,8 karantén. $\mathrm{Z}$ veřejných zpráv poté vyplynulo, že $\mathrm{k}$ nějaké formě dozoru nad dodržováním karantén ze strany Policie ČR mělo dojít. Srov. Policisté budou kontrolovat dodržování karantén a izolací, seznamy dodá hygiena. In: ČT24 [online]. 22. 3. 2021 [cit. 23. 3. 2021]. Dostupné z: https://ct24.ceskatelevize.cz/domaci/ 3287194-policiste-budou-kontrolovat-dodrzovani-karanten-a-izolaci-seznamy-doda-hygiena. Výsledek ovšem není dohledatelný.
} 
devším první verze z jara 2020, nicméně následný vývoj nebyl při hodnocení opomenut. Při jejich zkoumání byly zjištěny i vážnější nedostatky a neproporcionální zásahy do základních práv občanů.

Česká chytrá karanténa se skládala ze vzpomínkových map pracujících s daty od mobilních operátorů a bank, a aplikace eRouška. Obě řešení strádaly především kvůli téměř neexistujícímu zákonnému základu, přičemž tento problém není do dnešního dne uspokojivě vyřešen. Obě části je nicméně možné považovat za proporcionální zásahy. Ačkoliv následný vývoj směřoval $k$ větší ochraně soukromí, což lze hodnotit pouze pozitivně, některé problémy stále přetrvávají (nedůsledně zpracované DPIA vzpomínkových map a absence kvalitních právních norem).

Slovenská chytrá karanténa obsahovala systém státní karantény pro repatrianty a předávání údajů ÚVZ od mobilních operátorů. Oproti českému řešení zde sice zákonný základ existoval, nicméně jej není možné v mnohých ohledech považovat za dostatečný. A to i přes instrukce, které slovenskému zákonodárci poskytl Ústavní soud SR. Největším problémem ale je neproporcionálnost sledování lidí v izolaci skrze aplikaci eKaranténa, která představovala značný zásah do soukromí. Tento způsob vynucování izolace přitom není a priori neproporcionální, jen potřebuje odůvodnění založené na dostatečných datech o porušování nařízených karantén, $\mathrm{k}$ čemuž zde nedošlo.

Široké nasazení technologií je obecně nutné zhodnotit jako rozumný prostředek mající potenciál pomoci v boji s pandemií. Z předložené analýzy lze nicméně vydestilovat několik doporučení pro přîště:

- $\quad$ potřeba dostatečného právního základu - v těchto situacích by měl existovat specifický právní rámec, který bude explicitně stanovovat podmínky zpracování osobních údajů včetně dostatečných záruk;

- užitečnost opatření - př̀ nastavování chytrých karantén je u jednotlivých částí nutné se pozastavit nad jejich vhodností již v okamžiku prijímání. Příkladem opaku je absolutně nevyužitá pravomoc ÚVZ; 
- $\quad$ proporcionalita - je nutné se vždy zamýšlet nad proporcionalitou částí chytré karantény v konkrétní situaci, přičemž odůvodnění zásahu do práva na soukromí může být postaveno pouze na určitém (ne)chování lidí; a

- $\quad$ provázanost - s účinností chytrých karantén jsou inherentně spojeny další vlivy, jako jsou vhodně nastavená opatření, důvěra lidí a transparentnost řešení. I na to se musí státy zaměřit při koncipování a provozování chytrých karantén.

\section{POUŽITÉ ZDROJE}

[1] BARNEY, Gwenn. Does Schrems II Doom Use of SCCs for EU-US Data Transfers? No Answers and Clouds are Gathering. In: JD Supra [online]. 4.11. 2020 [cit. 22. 2. 2021]. Dostupné Z: https://www.jdsupra.com/legalnews/does-schrems-ii-doom-use-of-sccs-for-eu$15488 /$

[2] COUNCIL OF EUROPE DIRECTORATE GENERAL HUMAN RIGHTS AND RULE OF LAW. AI Breakfasts: Covid-19 - Myths and realities of tracking applications [online] [cit. 18. 5. 2020]. Dostupné z: https://www.youtube.com/watch?v=19d3B6AuvdI

[3] DOČEKAL, Daniel. Jak na iPhonech funguje trasování nákazy koronavirem (COVID-19 Exposure Tracing)? In: Lupa.cz [online]. 21. 5. 2020 [cit. 1. 9. 2020]. Dostupné z: https:// www.lupa.cz/clanky/jak-na-iphonech-funguje-trasovani-nakazy-koronavirem-covid-19-exposure-tracing/

[4] FIŠER, Miloslav. Aplikaci eRouška už používá 1,5 milionu lidí. In: Novinky.cz [online]. 31. 12. 2020 [cit. 12. 3. 2021]. Dostupné z: https://www.novinky.cz/internet-a-pc/software/ clanek/aplikaci-erouska-uz-pouziva-15-milionu-lidi-40346571

[5] JANN, Ole, Pavel KOCOUREK a Jakub STEINER. Využití technologie Bluetooth pro trasování šírení covid-19 [online]. Institut pro demokracii a ekonomickou analýzu, 2020 [cit. 5. 8. 2020]. Dostupné z: https://idea.cerge-ei.cz/files/IDEA_Trasovani_covid19_duben2020_14.pdf

[6] KLOUDA, Jan. Bez emocí to jde správně. In: LinkedIn [online]. 24. 3.2020 [cit. 5. 8. 2020]. Dostupné z: https://www.linkedin.com/pulse/bez-emoc\%C3\%AD-jde-spr \%C3\%A1vn\%C4\%9B-jan-klouda

[7] KMEC, Jiří et al. Evropská úmluva o lidských právech: komentár̆. Praha: C.H. Beck, 2012. ISBN 978-80-7400-365-3.

[8] MAĎAROVÁ, Helga. Schrems II: zásadná zmena v podmienkach prenosu osobných údajov mimo EÚ. In: epravo.sk [online]. 1. 10. 2020 [cit. 7. 3. 2021]. Dostupné z: https:// www.epravo.sk/top/clanky/schrems-ii-zasadna-zmena-v-podmienkach-prenosu-osobnychudajov-mimo-eu-4905.html 
[9] NEČÁSKOVÁ, Pavlína. Společné pokoje, odtažitý personál, destinace předem neznámá. Slováci sdílejí zážitky ze státní karantény. In: iROZHLAS [online]. 6. 5. 2020 [cit. 8. 3. 2021]. Dostupné z: https://www.irozhlas.cz/zpravy-svet/slovensko-statni-karantena-koronaviruscestovani-hranice_2005061304_kro

[10] NEŠPŮREK, Robert a Vojtěch BARTOŠ. EU-US Privacy Shield zrušen. Předávání osobních údajů do USA podle standardních smluvních doložek mohou úr̆ady kdykoliv zakázat. [online]. 2020 [cit. 20. 8. 2020]. Dostupné z: https://www.havelpartners.blog/blog/eu-us-privacyshield-zrusen-predavani-osobnich-udaju-do-usa-podle-standardnich-smluvnich-dolozek-mohouurady-kdykoliv-zakazat/147

[11] NULÍČEK, Michal et al. GDPR - obecné nař̌zení o ochraně osobních údajů. 2. vyd. Wolters Kluwer, 2018. ISBN 978-80-7598-068-7.

[12] NULÍČEK, Michal, Bohuslav LICHNOVSKÝ a Filip BENEŠ. Chytrá karanténa - proč $v$ Čes$k u$ potřebujeme souhlas? [online]. 2020 [cit. 5. 8. 2020]. Dostupné z: https://rowan.legal/ chytra-karantena-proc-v-cesku-potrebujeme-souhlas/

[13] OLEJNIK, Lukasz. Technology impact of Privacy Shield invalidation - is it the EU data localization? [online]. 2020 [cit. 1. 9. 2020]. Dostupné z: http://blog.lukaszolejnik.com/technology-impact-of-privacy-shield-invalidation-is-it-the-eu-data-localization/

[14] PIERUCCI, Alessandra a Jean-Philippe WALTER. Joint Statement on the right to data protection in the context of the COVID-19 pandemic. In: Council of Europe [online]. 2020 [cit. 18.05.2020]. Dostupné z: https://rm.coe.int/covid19-joint-statement/16809e09f4

[15] RÁMIŠ, Vladan et al. Předběžné vyjádření Spolku pro ochranu osobních údajů k novele zákona č. 127/2005 Sb., navržené Ministerstvem zdravotnictví 30.11.2020. In: epravo.cz [online]. 17. 12. 2020 [cit. 22. 3. 2021]. Dostupné z: https://www.epravo.cz/top/clanky/ predbezne-vyjadreni-spolku-pro-ochranu-osobnich-udaju-k-novele-zakona-c-1272005-sbnavrzene-ministerstvem-zdravotnictvi-30112020-112324.html

[16] SCHMIDT, Stephen. Customer update: AWS and the EU-US Privacy Shield [online]. 2020 [cit. 1. 9. 2020]. Dostupné z: https://aws.amazon.com/blogs/security/customer-update-awsand-the-eu-us-privacy-shield/

[17] ŠTRAHA, Štěpán a Martina RIEVAJOVÁ. UPDATE: Slovenský Úrad verejného zdravotníctva získal prístup $k$ vašim telefónnym číslam, aj ked’ mu prezidentka dala stopku [online]. 2020 [cit. 4. 10. 2020]. Dostupné z: https://www.havelpartners.blog/blog/slovensky-uradverejneho-zdravotnictva-nebude-mat-zatial-pristup-k-vasim-telefonnym-cislam-prezidentkamu-dala-stopku/157

[18] DE TERWANGNE, Cécile. Council of Europe convention 108 +: A modernised international treaty for the protection of personal data. Computer Law \& Security Review. 2021, roč. 40, s. 105497. ISSN 0267-3649. DOI: 10.1016/j.clsr.2020.105497

[19] WAGNEROVÁ, Eliška et al. Listina základních práv a svobod: komentář. Praha: Wolters Kluwer, 2012. ISBN 978-80-7357-750-6. 
[20] Aplikaci eRouška si zatím aktivoval milion lidí. Nové uživatele ,nalákala' SMS výzva. In: Lidovky.cz [online]. 14.10. 2020 [cit. 12. 3. 2021]. Dostupné z: https://www.lidovky.cz/ domov/aplikaci-erouska-si-zatim-aktivovalo-861-tisic-lidi-nove-uzivatele-nalakala-smsvyzva.A201014_142758_ln_domov_sei

[21] COVID-19 country overviews. In: Evropské stréedisko pro prevenci a kontrolu nemocí [online] [cit. 4. 10. 2020]. Dostupné z: https://covid19-country-overviews.ecdc.europa.eu/\#3_eueea_and_the_uk

[22] COVID-19: Inteligentná domáca karanténa by sa mala spustit od piatku. In: Ministerstvo zdravotníctva SR [online]. 19. 5. 2020 [cit. 8. 3. 2021]. Dostupné z: https://www.health.gov.sk/Clanok?covid-19-19-05-2020-karantena-smart

[23] Dopis předsedy Evropského sboru pro ochranu osobních údajů O. Micolovi [online]. Evropská sbor pro ochranu osobních údajů, [cit. 1. 9. 2020]. Dostupné z: https://edpb.europa.eu/sites/ edpb/files/files/file1/edpbletterecadvisecodiv-appguidance_final.pdf

[24] DPIA eRouška 2.0, v. 6 ze dne 4. 2. 2021

[25] Guide on Article 8 of the European Convention on Human Rights [online]. Evropský soud pro lidská práva, 2020 [cit. 1. 9. 2020]. Dostupné z: https://www.echr.coe.int/documents/ guide_art_8_eng.pdf

[26] Chytrá karanténa - Aktuální informace o COVID-19. In: Ministerstvo zdravotnictví ČR [online] [cit. 5. 8. 2020]. Dostupné z: https://koronavirus.mzcr.cz/chytra-karantena/

[27] Informace o zpracování osobních údajů dle mimořádného opatření Ministerstva zdravotnictví ve věci předávání údajů o místě a době použití elektronického platebního prostředku [online]. Moneta Money Bank, [cit. 1. 9. 2020]. Dostupné z: https://www.moneta.cz/documents/ 20143/11740692/mmb-informace-o-zpracovani-osobnich-udaju-chytra-karantena.pdf

[28] Lidé porušují karanténu. V lednu ji nedodržela třetina z pěti set kontrolovaných. In: $A k$ tuálně.cz [online]. 4. 2. 2021 [cit. 12. 3. 2021]. Dostupné z: https://zpravy.aktualne.cz/domaci/karantenu-porusila-v-lednu-tretina-kontrolovanych/r $\sim \mathrm{c} 369 \mathrm{cb}-$ de66f711eb842f0cc47ab5f122/

[29] Materiál č. j. OVA 971/20. In: Portál Aplikace ODok [online] [cit. 22. 3. 2021]. Dostupné z: https://apps.odok.cz/veklep-detail?pid = KORNBSNH56J5

[30] Notifications under Article 15 of the Convention in the context of the COVID-19 pandemic. In: Council of Europe [online] [cit. 18. 2. 2021]. Dostupné z: https://www.coe.int/en/ web/conventions/full-list/-/conventions/webContent/62111354

[31] Ochrana soukromí a cookies eRoušky. In: eRouška [online] [cit. 8. 5. 2020]. Dostupné z: https://erouska.cz/podminky-pouzivani

[32] Ombudsmanka odporúča zmenit’ systém povinnej štátnej karantény - tisková zpráva [online]. Kancelária verejného ochrancu práv, 2020 [cit. 8. 3. 2021]. Dostupné z: https:// www.vop.gov.sk/files/2020_23_TS_VOP_odporuca_zmenit_system_povinnej_statnej_karanteny.pdf 
[33] Ombudsmanka sa obrátila na Ústavný súd, žiada posúdenie zásahov do práv počas pandémie. In: RTVS: Správy [online]. 10. 2. 2021 [cit. 8. 3. 2021]. Dostupné z: https://spravy.rtvs.sk/2021/02/ombudsmanka-sa-obratila-na-ustavny-sud-ziada-posudenie-zasahov-do-pravpocas-pandemie/

[34] Podmienky ochrany súkromia - eKaranténa. In: Korona.gov.sk [online] [cit. 4. 10. 2020]. Dostupné z: https://korona.gov.sk/podmienky-ochrany-sukromia-ekarantena/

[35] Policisté budou kontrolovat dodržování karantén a izolací, seznamy dodá hygiena. In: ČT24 [online]. 22. 3. 2021 [cit. 23. 3. 2021]. Dostupné z: https://ct24.ceskatelevize.cz/domaci/3287194-policiste-budou-kontrolovat-dodrzovani-karanten-a-izolaci-seznamy-doda-hygiena

[36] Projects using personal data to combat SARS-CoV-2. In: GDPRHUB.eu [online] [cit. 12. 4. 2020]. Dostupné z: https://gdprhub.eu/index.php? title $=$ Projects_using_personal_data_to_combat_SARS-CoV-2

[37] Respecting democracy, rule of law and human rights in the framework of the COVID-19 sanitary crisis: A toolkit for member states [online]. Council of Europe, 2020 [cit. 14. 5. 2020]. Dostupné z: https://rm.coe.int/sg-inf-2020-11-respecting-democracy-rule-of-law-and-humanrights-in-th/16809e1f40

[38] RP: Návrh zákona o elektronických komunikacích je protiústavní. In: Advokátní deník [online]. 19. 1. 2021 [cit. 22. 3. 2021]. Dostupné z: https://advokatnidenik.cz/2021/01/19/ rozumne-pravo-navrh-zakona-o-povinnem-predavani-dat-operatory-je-protiustavni/

[39] Smart karanténa - najčastejšie otázky ohladne karantény v domácej izolácii s využitím aplikácie eKaranténa. In: Korona.gov.sk [online] [cit. 4. 10. 2020]. Dostupné z: https://korona.gov.sk/najcastejsie-otazky/ekarantena/

[40] Sněmovní tisk 1158. In: Poslanecká sněmovna Parlamentu ČR [online] [cit. 23. 3. 2021]. Dostupné z: https://www.psp.cz/sqw/historie.sqw?o $=8 \& \mathrm{t}=1158$

[41] Souhrnná DPIA eRouška v. 0.2

[42] Souhrnná DPIA Jednotný informační systém KHS pro podporu call centra a vzpomínkové mapy v. 1.09

[43] ÚOOÚ k projektu „chytrá karanténa“. In: Úřad pro ochranu osobních údajů [online]. 11. 4. 2020 [cit. 1. 9. 2020]. Dostupné z: https://www.uoou.cz/uoou-k-nbsp-projektu-chytrakarantena/d-41769

[44] Ústavný súd prijal moje podanie na d’alšie konanie. In: Verejný ochranca práv [online]. 30. 4. 2021 [cit. 20. 5. 2021]. Dostupné z: https://www.vop.gov.sk/stavn-s-d-prijal-mojepodanie-na-al-ie-konanie

[45] Vyjádření Spolku pro ochranu osobních údajů k projektům Chytrá karanténa a eRouška [online]. Spolek pro ochranu osobních údajů, 2020 [cit. 1. 9. 2020]. Dostupné z: https:// www.ochranaudaju.cz/wp-content/uploads/2020/05/Chytra_karantena_stanovisko_final.pdf

[46] Vyjádření Úřadu k rezervačnímu systému očkování proti COVID-19. In: Úřad pro ochranu osobních údajů [online]. 1. 2. 2021 [cit. 22. 2. 2021]. Dostupné z: https://www.uoou.cz/vyjadreni-uradu-k-nbsp-rezervacnimu-systemu-ockovani-proti-covid-19/d-47761 
[47] Zapojení bank do „Chytré karantény“. In: Česká bankovní asociace [online]. 27. 4. 2020 [cit. 1. 9. 2020]. Dostupné z: https://cbaonline.cz/zapojeni-bank-do-chytre-karanteny

Toto dílo lze užít v souladu s licenčními podmínkami Creative Commons BY-SA 4.0 International (http://creativecommons.org/licenses/by-sa/4.0/legalcode). 